AL-QANTARA

XL 1, enero-junio 2019

pp. $185-217$

ISSN 0211-3589

https://doi.org/10.3989/alqantara.2019.006

\title{
Estudio y enseñanza del hebreo bíblico en la Córdoba califal (929-1031)*
}

\author{
Study and Teaching of Biblical Hebrew in \\ the Caliphate of Córdoba (929-1031)
}

\author{
José Martínez Delgado \\ Universidad de Granada \\ https://orcid.org/0000-0001-7595-3912
}

\begin{abstract}
A partir de las descripciones de las políticas de mecenazgo aplicadas por los califas omeyas de Córdoba y los períodos educativos de la época se reinterpretan todos los datos conocidos sobre los filólogos hebreos y el estudio del hebreo bíblico en la capital de al-Andalus durante el califato, confirmando que los judíos participaron y se beneficiaron de dichas políticas explotándolas hasta sus últimas consecuencias.
\end{abstract}

Palabras clave: Califato; Judíos de al-Andalus; Hebreo bíblico; Filólogos hebreos.
On the basis of the descriptions of the sponsorships and patronage policies applied by the Umayyad caliphs of Córdoba and the educational stages of the time, all the well-known data on the Hebrew philologists and the study of biblical Hebrew in the capital of al-Andalus during the caliphate are reinterpreted, confirming that the Jews participated and benefited from these policies by exploiting them in all their ramifications.

Key words: Caliphate; Jews of al-Andalus; Biblical Hebrew; Hebrew philologists.

\section{Ubicación de la judería}

Todos los datos topográficos que encontramos en las fuentes de la época sobre puertas y arrabales de Córdoba nos sugieren que, al menos durante el período que nos ocupa, la judería de Córdoba se ubicaba al

* Este trabajo se encuadra dentro del proyecto de investigación "Recuperación y estudio del legado lingüístico judeo-árabe de al-Andalus" (FFI2014-51818-P).

Copyright: (C) 2019 CSIC. Este es un artículo de acceso abierto distribuido bajo los términos de la licencia de uso y distribución Creative Commons Reconocimiento 4.0 Internacional (CC BY 4.0). 
norte del cauce del río Guadalquivir, ${ }^{1}$ extramuros de la ciudad, ${ }^{2}$ seguramente una vez superada la zona industrial de Tejares (dār al-tirāzz) y Ollerías, ${ }^{4} \mathrm{y}$ en paralelo a lo que fue el barrio cristiano hasta la gran expansión urbana del siglo $\mathrm{x},{ }^{5}$ es muy posible además que su ubicación fuese anterior a la conquista islámica. Debió de ser destruida junto con el resto de arrabales durante la revuelta bereber, seguramente en los asedios que sufrió la ciudad entre los años 1010-1013.

\section{Generaciones de filólogos hebreos durante el califato}

Durante el siglo que va a durar el califato de Córdoba y su esplendor con los califas 'Abd al-Raḥmān III (929-961), al-Ḥakam II (961-976) y Hišam II (976-1009 y 1010-1013) se van a suceder al menos tres generaciones de sabios judíos dedicados al estudio de la lengua hebrea clásica en la capital de al-Andalus:

La primera generación de filólogos hebreos medievales viene representada por dos figuras centrales y enfrentadas: Mĕnahem b. Saruq ${ }^{6}$

1 Su ubicación actual en el corazón de la madīna debe datarse como mínimo en época almohade, véase González, Reinado y diplomas, v. I, p. 438 y v. III, p. 233. Ashtor mantenía que la ubicación actual de la judería es la original y que la que encontramos al norte en época califal surgió como resultado de la expansión urbanística experimentada en el siglo X; véase Ashtor, The Jews of Moslem Spain, Vol. I pp. 294-299.

2 Así se intuye a partir de la relación de la puertas y arrabales de al-Maqqarī en Nafh

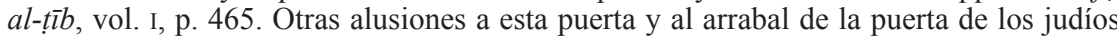
( rabad bāb al-yahūd) pueden encontrarse en al-Hušanī, Historia de los jueces de Córdoba, pp. 112-113; al-Muqaddasī, Kitāb ahsan al-taqū̄ìm, p. 233; al-Idrīsī, Description de l'Afrique, p. 208; y véase además Zanón, Topografía de Córdoba Almohade, pp. 28 y 42.

${ }^{3}$ En septiembre del año 972 el califa al-Ḥakam II visitó los talleres de dār al-tirāaz accediendo a ellos a través del cementerio (Umm Salama) de la puerta de los judíos (bāb alyahüd, en la actualidad Puerta de Osario), véase Ibn Hayyān, Anales palatinos, pp. 115-116. Véase además una síntesis de los datos en Arjona Castro, "La judería en la Córdoba del emirato y califato". Para los versos que Ibn Šuhayd dedica a esta puerta véase Hiedra Rodríguez, "Ibn Shuhayd on Joseph".

${ }^{4}$ En esa zona apareció la lápida hebrea de Córdoba más antigua conocida hasta el momento, epitafio de Yěhudah bar Abūn (no Akūn) datado en el año 845, y véase el informe en Larrea Castillo y Hiedra Rodríguez, "La lápida hebrea de época emiral".

${ }^{5}$ Véase el estudio sobre la evolución de la zona por Carmona Berenguer, "Casa pórtico de época califal".

${ }^{6}$ Para Měnahem b. Saruq véanse, además de obras de referencia, Filipowski, The first Hebrew and Chaldaic Lexicon; Yahalom y Sáenz-Badillos, “Arikah wěnusah"; Sáenz Badillos, "Los hapax legomena bíblicos"; Sáenz-Badillos, Maḥberet Měnahem; Sáenz-Badillos y Targarona, Gramáticos hebreos de al-Andalus, pp. 23-38; Fleischer, 
y Dunaš b. Labraț. ${ }^{7}$ Ambos cuentan con discípulos de los que tenemos constancia gracias a las defensas (Těšubot) que hicieron de sus respectivos maestros. ${ }^{8}$ Los del primero son Yișhaq b. Ğiqațela, ${ }^{9}$ Yișhaq b. Qafrūn ${ }^{10}$ y Abū Zakariyā' Yahyā b. Dā' ūd $a l-F \bar{a} s \bar{l}$, conocido por su laqab o apodo romance, Ḥayyūğ (léase Ḥayyūcho) y como Yěhudah b. Daud en las fuentes hebreas; ${ }^{11}$ mientras que del segundo sólo nos ha llegado el nombre y la obra de Yěhudī b. Šešat. ${ }^{12}$ Podemos datar la obra de estos seis lingüistas en torno al año $958,{ }^{13}$ es decir, a finales del reinado de

"Lě-qadmuniyot širatenu bi-Sfarad"; Sáenz-Badillos, Literatura hebrea en la España medieval, pp. 25-34; Sáenz-Badillos y Targarona, Los judios de Sefarad ante la Biblia, pp. 55-76; Elwolde, "The Maḥberet of Menahem"; Sáenz Badillos y Martínez Delgado, "En torno al Mahberet".

${ }^{7}$ Para Dunaš b. Labrat veánse Filipowski, Těšubot Dunaš ben Labraț; Allony, The Scansion of Medieval Hebrew Poetry; Sáenz-Badillos, Tešubot de Dunaš ben Labrat; Sáenz-Badillos, "Les Tešubot de Dunaš ben Labraț"; Sáenz-Badillos, "La hermenéutica bíblica de Dunaš ben Labrat"; Sáenz-Badillos y Targarona, Gramáticos hebreos de al-Andalus, pp. 39-63; Sáenz-Badillos, Literatura hebrea en la España medieval, pp. 34-40; Morag, "Maḥăloqet Měnaḥem wě-Dunaš".

${ }^{8}$ Stern, Těšubot talmide Menahem; Varela Moreno, Tešubot de Yehudi ben Šešet; Benavente, Tešubot de los Discípulos de Měnahem; Gaash, "The Responses (Teshuvot) of Menahem's Disciples against Dunash".

9 Para el autor véase Sáenz-Badillos y Targarona, Gramáticos hebreos de al-Andalus, pp. 65-78; Sáenz-Badillos, Literatura hebrea en la España medieval, pp. 57-62; Schirmann, The History of Hebrew Poetry in Muslim Spain, pp. 141-143; Benavente, Tešubot de los Discípulos de Měnaḥem; Zulay, "Azharot R. Yișhaqa b. Ğiqațela".

${ }^{10}$ Para el autor véase Sáenz-Badillos y Targarona, Gramáticos hebreos de al-Andalus, pp. 65-78; Sáenz-Badillos, Literatura hebrea en la España medieval, pp. 57-62.

${ }_{11}$ Para el autor véanse Jastrow, The weak and geminative verbs in Hebrew; Ben-Hayyim, "Lě-"inyan kělale ha-šěwa"”; Eldar, "Gilgulo šel musag al-sākin al-layīn"; Sáenz-Badillos y Targarona, Gramáticos hebreos de al-Andalus, pp. 95-108; Sivan, "Hayyūğ hayah hogeh qameș sěfardi"; Sivan, "Biblical Hebrew Roots and Quiescents"; Eldar, "The Grammatical Theory of Hayyūj"; Sáenz-Badillos, Literatura hebrea en la España medieval, pp. 74-77; Sáenz-Badillos y Targarona, Los judios de Sefarad ante la Biblia, pp. 77-79; Basal, Kitāb al-nutaf; Martínez Delgado, El Libro de Hayyūŷ;; Martínez Delgado, "El Opúsculo sobre la Normativa Vocálica”; Sara y Mauck, Yehuda ben David Hayyuwj: Tanqiyt; Sivan y Wated, Three treatises on Hebrew grammar.

12 Sáenz-Badillos y Targarona, Gramáticos hebreos de al-Andalus, pp. 79-82.

13 Obtenemos la fecha del dato ofrecido por Dunaš b. Labrat en su panegírico a Hasday b. Šaprut donde describe la llegada a Córdoba de una embajada cristiana en el año 958:

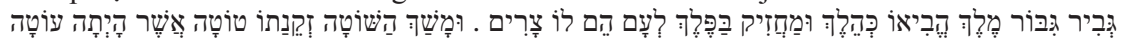
(musammat murabba;, metro mustațil modificado con taš 'ît: mafá 'īlun fi 'lan, rima -yim) 'a un señor fuerte, rey, lo trajo cual vagabundo, apoyado en un bastón, a un pueblo que era su enemigo / y arrastró a la salvaje, su abuela Toda, que estaba cubierta de realeza como los señores / con la fuerza de su sabiduría y el poder de su prudencia, con sus grandes artes y la dulzura de sus palabras' (Sáenz-Badillos, Tešubot de Dunaš ben Labrat, p. 2*). 
'Abd al-Raḥmān III y comienzos del de al-Hakam II y compondrán sus obras hebreas bajo el mecenazgo del naśì 'Hasday b. Šaprūṭ al que dedicarán largos poemas introductorios. ${ }^{14}$ En cambio, las obras redactadas en judeo-árabe por Ḥayyūğ ya no incluirán composiciones laudatorias ni mención a mecenas alguno ${ }^{15}$ quizá haya que datarlas entre los años 970-975, lustro propuesto para el óbito de Ibn Šaprūṭ.

La segunda generación es, sin duda, la peor conocida, apenas nos han llegado nombres y a veces, con suerte, alguna nota peregrina sobre sus aportaciones filológicas. Son, en todo caso, discípulos de los anteriores que aun vivirían. Los nombres que nos han llegado son Abū 'Amr b. Yaqwā' y Abū Zakariyā' Yahyā b. Hanīgā, ${ }^{16}$ ambos docentes de lengua hebrea clásica en Córdoba. ${ }^{17}$ En este grupo hay que incluir a los hijos de Ibn Šaprūṭ, al menos Abū 1-Walīd b. Hasday, que bien pudo heredar el cargo de naśí' ( $r \bar{a}$ 'is) de su padre hasta el nombramiento del sedero Ya‘ăqob b. Ğaw por Almanzor (977-1002) o sustituir a este durante su ingreso en prisión, ${ }^{18} \mathrm{y}$ del que sabemos a ciencia cierta que se

${ }^{14}$ Se trata de una sucesión de mușammaț murabba ' (bbba ccca ddda ...) en forma de mu 'aradah, metro mustațìl modificado con taš 'ịt: mafā 'ìlun fi 'lan, rima -yim. Esta fórmula métrica se consagró como clásica y así ha sido reproducida y empleada exclusivamente en el género musammat (tanto mutallat como murabba) por los cuatro grandes poetas hebreos del siglo de oro (mediados del siglo XI-mediados del s. XII): Samuel b. Nagrela, Šĕlomo b. Gabirol, Mošeh b. 'Ezra y Yěhuda ha-Leví. Por su lado, Ya‘ăqob b. El'azar lo cataloga como una variante de hazağ (Yahalom, Judaeo-Arabic Poetics, p. 88) sin que la ciencia métrica permita esta secuencia en dicho metro.

15 Jastrow, The weak and geminative verbs in Hebrew; Basal, Kitāb al-nutaf; Martínez Delgado, El Libro de Hayyūŷ; Martínez Delgado, "El Opúsculo sobre la Normativa Vocálica"; Sara y Mauck, Yehuda ben David Hayyuwj: Tanqiyt; Sivan y Wated, Three treatises on Hebrew grammar.

16 Tenemos noticias de ellos a través de Mošeh ibn 'Ezra, Kitāb al-muhāạara walmud̄ākara f. 31r, según él, ambos eran seguidores de Yiṣ̣aq b. Qafrūn y del poeta haKohen b. al-Mudarram.

17 Ibn Ğanāḥ trae a colación un comentario de Abū 'Amr b. Yaqwā' (The book of Hebrew roots, c. 70) en el que le critica por haber considerado que la ambigua forma hebrea

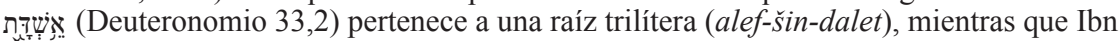
Ganāḥ considera que son dos palabras que se han montado por error, tal y como demuestra

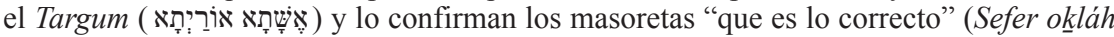
wě-okláh, Lista 82: Quince palabras que están escritas como una sola palabra pero que deben leerse como dos palabras; ed. F. Díaz Esteban, Madrid, 1975). Sobre Abū Zakariyā' b. Haniga', Ibn Ğanāḥ nos cuenta que este estaba en Córdoba con el poeta Abū Ibrahīm b. Haifūn y que modificaron, por error, una palabra de un verso enviado por Yișhaq b. Mar Ša'ul elogiando a Ya ‘ăqob [b. Ğaw?] y a su hijo (Derenbourg, Livre des parterres fleuris, pp. 207-208 y véase más adelante la nota 99).

18 Así lo titula Mošeh ibn 'Ezra, Kitāo al-muhādara wal-mudākara f. 31v. Véase más adelante la anécdota de Ibn Ğanāḥ en los jardines privados de la residencia del visir Ibn Šuhayd. 
ocupó de la lengua hebrea clásica e incluso la enseñóo. ${ }^{19}$ Quizá haya que incluir aquí también a Adoniah ha-Levī, tanto tiempo identificado con Dunaš b. Labrat y autor de un escrito contra el célebre sabio oriental Să 'adyah al-Fayyūmī (882-942). ${ }^{20}$ Se cree que en un verso de su obra está alabando al naśì' Ya ‘ăqob b. Ğaw, lo cual sería indicio de que redactó su obra después del año 977; ${ }^{21}$ lo mismo puede decirse de un poema que Yiṣ̣̣aq b. Mar Ša'ul envía a Córdoba. ${ }^{22}$

La tercera y última generación nacerá y se formará en Córdoba pero se verán obligados a exiliarse debido a los disturbios que llevaron a la desintegración del califato a partir del año 1013. Hay que entender que por entonces Córdoba debía albergar a numerosos sabios y especialistas en filología hebrea pero son dos grandes figuras las que eclipsan a todos esos posibles autores: Abū 1-Walīd Marwān b. Ğanāḥ (c. 970 - d. 1038) ${ }^{23}$ y Abū Ibrāhīm Ismā‘īl (Šĕmu'el) b. Nagrela (993-1056). ${ }^{24}$ A pesar de la diferencia de edad entre ambos, comparten una serie de características que los hace herederos y difusores del legado califal por los distintos reinos taifa en los que se descompuso al-Andalus tras la guerra civil que se desató en Córdoba.

${ }_{19}$ Así se deduce de las palabras de Ibn Ğanāh en su obra Risālat al-taqrīb wa-l-tashīl p. 123 y véase más adelante nota 103 .

20 Su obra fue editada por Schröter, Kritik des Dunasch ben Labrat. Véase un estudio de sus contenidos en Sáenz-Badillos y Targarona, Gramáticos hebreos de al-Andalus, pp. 83-89 y Sáenz-Badillos, "Sobre el autor de las Tešubot 'al Sě‘adyah". Para su identificación véase Hazon, "Sefer Tiqqun Shegagot".

${ }_{21}$ Schröter, Kritik des Dunasch ben Labrat, p. 30.

22 Derenbourg, Livre des parterres fleuris, pp. 207-208 y véase la nota 99.

${ }^{23}$ Las obras monográficas de referencia sobre Ibn Ğanāḥ y las principales ediciones de sus obras sobre filología hebrea son las de Munk, "Notice sur Abou'l-Walid"; Derenbourg, Livre des parterres fleuris; Derenbourg - Derenbourg, Opuscules et traités d'Abou'l-Walid; Neubauer, The book of Hebrew roots; Gallego, El judeo-árabe medieval; Martínez Delgado, "Risālat al-Tanbīh by Ibn Ǧanāḥ"; Alahmad Alkhalaf - Martínez Delgado, Risālat al-taqrīb wa-l-tashīl; Bacher, Sepher haschoraschim; Camacho Padilla, "Rabí Yonâ ben Gannach. La segunda mitad del Sefer Hahaxua"; Metzger, Le livre des parterres fleuris; Téné, Sefer ha-Hassaga; Wilensky, Sefer ha-riqmah; Busi, "Materiali per una storia della filologia",; Sáenz Badillos-Targarona, Gramáticos hebreos de al-Andalus, pp. 109-147; Becker, Arabic Sources of R. Jonah ibn Janāh's Grammar; Téné "Ibn Janāḥ, Jonah"; Martínez Delgado, “[1354] Ibn Ŷanāḥ, Marwān”; Martínez Delgado , "Ibn Janāḥ, Jonah (Abū 'l-Walīd Marwān)",.

${ }^{24}$ Las breves muestras sobre la producción de Ibn Nagrela que nos han llegado fueron editadas por Derenbourg et Derenbourg, Opuscules et traités d'Abou'l-Walid, pp. LIXLXVI; y Kokóvtsov, Novye materīaly. Véase además Sáenz Badillos-Targarona, Gramáticos hebreos de al-Andalus, pp. 124-129. 


\section{Políticas educativas y de mecenazgo de los omeyas}

Para entender en su justa medida el desarrollo intelectual de la comunidad judía de Córdoba, que pasó literalmente del anonimato a configurarse como los líderes intelectuales de las comunidades judías de todo el orbe islámico medieval, hay que prestar atención a las distintas políticas de mecenazgo desarrolladas durante el reinado de los tres califas omeyas.

Las propias fuentes reconocen que la comunidad emerge intelectualmente bajo el mandato de 'Abd al-Raḥmān III (929-961) y a través de la figura del naśī’ Hasday b. Šaprūt alrededor del año 4700 de la creación del mundo (940), ${ }^{25}$ coincidiendo en el tiempo con el traslado de la corte al complejo palatino y administrativo de Madinat al-Zahrā'. Es, por tanto, un período de estabilidad política y el inicio del gran esplendor de Córdoba. El califa se va a encargar de desplegar toda una política de facilidades para que la gente, no sólo sabios, se instale en al-Andalus y específicamente en Córdoba. ${ }^{26}$ Así, en el caso de la judería, encontramos que primero llegan del propio territorio andalusí invitados por Hasday b. Šaprūt, como el caso del retorno de Mĕnahem b. Saruq; ${ }^{27}$ y más tarde llegan del extranjero, como Dunaš b. Labrat, que se había formado en las academias de Babilonia con Să adyah alFayyūmī y había tenido el acierto de adaptar la métrica árabe a la lengua hebrea; ${ }^{28} \mathrm{o}$ el célebre juez Mošeh $b$. Hanok, posiblemente de origen italiano, portador de la tradición palestinense y del que se forjó toda una leyenda sobre su llegada a Córdoba. ${ }^{29}$ Estos tres hombres sentarán en apenas veinte años las bases de los tres grandes pilares del legado hebreo andalusí: lexicografía, poesía y derecho.

Sabemos que durante el reinado de 'Abd al-Raḥmān III, los maestros mantuvieron la tradición y el permiso para enseñar en las mezquitas

${ }^{25}$ Mošeh ibn 'Ezra, Kitāb al-muhāọara wal-mudāakara f. 30.

26 'Īsā, Tärīh al-ta 'ìm fì l-Andalus, p. 109.

27 Schirmann, Ha-širah ha- 'ibrit bi-Sfarad u-bĕ-Provans, vol. I, pp. 24-25, versos 306-308: recuerde también, mi señor, que me has hecho venir de lejos, de dehesa tranquila, I me has arrastrado desde un buen pastizal, me has sacudido de mi aprisco; / corrí, me di prisa y vine.

${ }^{28}$ Schirmann, The History of Hebrew Poetry in Muslim Spain, pp. 119-129. Sobre la métrica hebrea andalusí véase Martínez Delgado, Un manual judeo-árabe de métrica hebrea andalusí.

${ }^{29}$ Sáenz-Badillos, Literatura hebrea, pp. 63-65. 
de Córdoba ${ }^{30}$ y de forma análoga encontramos el mismo uso en los templos judíos; en la leyenda que nos relata la llegada del juez Mošeh b. Hanok se nos transmite que el juez de los judíos de Córdoba, Natán, ejercía, aunque con poco acierto, el magisterio de textos legales en la sinagoga del Midraš. ${ }^{31}$ Incluso los maestros de provincias podían venir y asentarse en la capital o bien volver a su hogar al terminar su magisterio, ${ }^{32}$ esto ayudaría a entender el trasiego de sabios entre Córdoba y Lucena, como el caso de Yiṣḥaq b. Ğiqațela y Yișhaq b. Mar Ša'ul, ilustres lucentinos de los que tenemos constancia que ejercieron su magisterio en Córdoba, como veremos más adelante.

Con 'Abd al-Raḥmān III se incrementa el interés por los libros, tanto por su composición como por su adquisición, incluso recurriendo para ello a mensajeros. ${ }^{33}$ En este aspecto, sabemos que el propio Hasday b. Šaprūṭ encarga personalmente a Měnaḥem b. Saruq que redacte su Mahberet, primer diccionario hebreo-hebreo de la historia. ${ }^{34}$ Este impresionante léxico debió de concluirse alrededor del año 958, momento en el que podemos datar la crítica (Těšubot) que recibió por parte de Dunaš b. Labrat. ${ }^{35}$ A partir de aquí los discípulos de ambos redactarán sus respectivas defensas sin que sepamos el período de tiempo exacto que ocupó este proceso de producción, salvo que son anteriores a la muerte de Ḥasday b. Šaprūt, al que todos homenajean con panegíricos escandidos. Gracias a estas obras sabemos que para entonces en Córdoba ya había libros imprescindibles para el estudio del hebreo bíblico, como rollos perfectamente vocalizados en sus versiones tiberiense y babilónica y entendemos que con su correspon-

30 'Īsā, Tārīh al-ta 'ì̀m fì l-Andalus, p. 110.

31 Abraham ibn Daud, Sefer ha-Qabbalah, p. 47 de la edición).

32 'Īsā, Tärīh al-ta 'lìm fí l-Andalus, p. 110.

33 'Īsā, Tärīh al-ta 'lìm fì l-Andalus, p. 111.

${ }^{34}$ Schirmann, Ha-širah ha- 'ibrit, vol. I, p. 25, versos 315-323: Nada más llegar / me encargaste una labor de estudio, un trabajo sobre la lengua santa / y dije "así será, mi señor" / y eché mi corazón al vuelo y lo fortaleci / convertí a mis riñones en mis consejeros y eran los que respondian con juicio / conmigo perdieron el sueño mis párpados y mi alma negó conceder el sueño a mis ojos / hasta satisfacer los asuntos de mi señor y colmar el anhelo de sus deseos. / Por Dios y por tu vida, si no cumpli tus órdenes / con cuita y penuria, en plena desnudez y carencia total. Échese a perder mi ojo derecho si yo hubiese tenido al alcance cuanto necesitaba / y no me hubiese fundido a fuego en el crisol del hambre.

35 Véase la nota 13. 
diente masora ${ }^{36}$ tratados de listas masoréticas, como el célebre e importante Sefer okláh wě-oklláh; ${ }^{37}$ obras contemporáneas como las de Să'adyah al-Fayyūmī, con toda seguridad su proto-diccionario conocido como Egron; ${ }^{38}$ y la tan criticada por entonces Risālah del comparatista magrebí Yěhudah b. Qurayš. ${ }^{39}$ Las fuentes dan testimonio de que Hasday b. Šaprūṭ no escatimó en conseguir libros y abastecer a las bibliotecas hebreas de Córdoba de obras de referencia para la producción de obras locales. ${ }^{40}$ Es factible además que esos mismos mensajeros que empleaba insistentemente, bien aprovechando las valijas diplomáticas oficiales, bien por iniciativa propia, para hacer llegar su famosa carta a Yosef, rey de los judíos Jazares, ${ }^{41}$ se encargasen de traerle obras de Oriente y el Magreb.

36 Véase por ejemplo, Sáenz-Badillos, Těšubot de Dunaš ben Labraț, p. XVII y en el propio texto p. 78* y 87 de la traducción. Quizá el caso más representativo es el del Kitāb al-mustalhaq de Ibn Ğanāh (Derenbourg y Derenbourg, Opuscules et traites d'Abou'l-

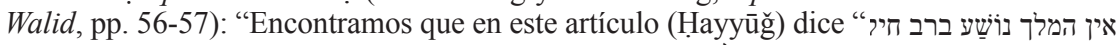
(Sal 33,16), patah porque es un perfecto nif'al, y ישראל נוֹשָׁע ביי (Is 45,17), qameș porque es un participio nif'al'. Dijo Marwān: la realidad en ambos casos es lo contrario, pues

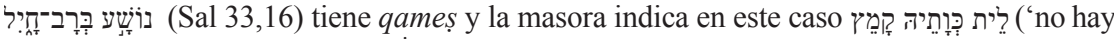

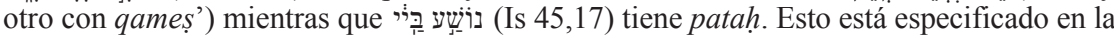
masora cuando se dice en el caso de

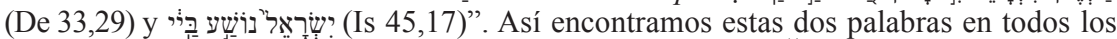
rollos de mejor calidad y así están registradas en la Masora Ǒkláh wě-Oḱkláh, que es la obra más exacta que poseemos sobre masora; tal vez este error en la obra de Abū Zakariyā' se deba al copista" (véase ed. Díaz Esteban, lista 25, p. 69). Por otro lado, en Rasā'il alrifāq se afirma que en la copia autógrafa de Ḥayyūğ la secuencia coincide con la de la masora (Firk Ebr-Arab. II 1239: 6r:1-2 y Derenbourg y Derenbourg, Opuscules et traités d'Abou'l-Walid, p. LXIII) y así aparece además en la práctica totalidad de los manuscritos y ediciones del libro de Hayyūğ, salvo en T-S Ar. 31.198 2r:1.

37 Véase Martínez Delgado, "From Bible to lexicography through the masora on alAndalus".

38 A. Sáenz-Badillos, Maḥberet Měnahem, p. 134*: "He encontrado en el capítulo de

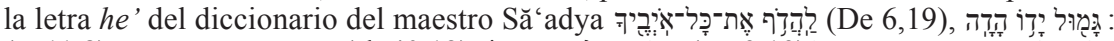

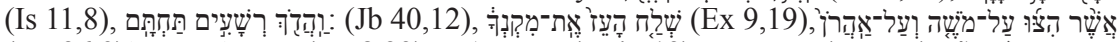

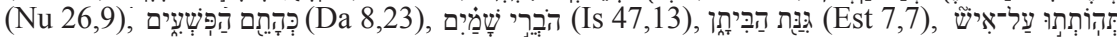
$($ Sal 62,4$)$ y como estas hay muchas en letras (= capítulos) que no forman parte de la base (yěsod) de las palabras" y cf. Allony, Ha'egron, pp. 211-213.

${ }^{39}$ El texto fue editado por Becker, The Risāla of Judah ben Quraysh. Sin embargo, hay que reconocer que los casos aducidos por Měnahem $b$. Saruq no coinciden con los del textus receptus en la actualidad, quizá se trate de otra obra y véase Becker, The Risāla, pp. 13-17.

${ }^{40}$ Mošeh ibn 'Ezra, Kitāb al-muhāẹara wal-mud̄ākara f. 30-30v.

${ }^{41}$ Sobre los distintos intentos para hacer llegar esta célebre misiva al rey Yosef véase Martínez Delgado, "La carta al rey de los Jazares". 
El siguiente califa, al-Ḥakam II (961-976), no sólo va a continuar con estas políticas de mecenazgo sino que va a incrementarlas, ya que él mismo es, en cierta manera y a la vez, motor y producto de las políticas aplicadas por su padre en materia de educación. ${ }^{42}$ Hasday $b$. Šaprūṭ seguirá al frente de la comunidad hasta su fallecimiento (c. 970975) durante todo el reinado de este califa, por lo que es fácil sospechar un continuismo en materia cultural. Se sigue atrayendo a sabios e incluso aumenta la inmigración de orientales y magrebíes que vienen a estudiar con los ya celebres maestros cordobeses de la primera generación y sus discípulos, como se verá más adelante con el caso de Mošeh b. Hanok.

El califa al-Hakam II va a manifestar siempre un profundo respeto hacia los sabios, incluidos los judíos a los que también realizaba encargos. ${ }^{43}$ El caso más célebre es el de Yosef ibn Abitur, discípulo del juez Mošeh b. Hanok, que según las fuentes interpretó (pirešs=fassara) todo el Talmud en árabe para el califa. ${ }^{44}$ Aunque era digno heredero de suceder a Mošeh b. Ḥanok en el cadiazgo de la comunidad, a la muerte de Ḥasday b. Šaprūṭ la comunidad prefirió proponer a Hanok b. Mošeh, pretendiendo que el hijo heredara el cargo de su padre, y así se presentaban a diario en Madīnat al-Zahrā' para hacérselo saber al califa, que, en un gesto entrañable, le confesó a su amigo Yosef ibn Abitur que "si los musulmanes me despreciasen como lo hacen contigo los judíos yo huiría, así que huye", ${ }^{45}$ demostrando además un profundo respeto hacia las cuestiones internas de la comunidad en las que no se iba a inmiscuir, limitándose a tramitar los nombramientos propuestos. ${ }^{46}$

Es muy posible que los judíos se hiciesen eco de la fundación de escuelas públicas por parte de al-Ḥakam II y lo imitasen. ${ }^{47} \mathrm{~A}$ tenor de

42 'Īsā, Tārīh al-ta 'ì̄m fì l-Andalus, pp. 125-142.

43 Por ejemplo, el caso del astrólogo judío al-Manșūr b. Abraham y véase Ashtor, The Jews of Moslem Spain, Vol. I, p. 363, n. 9.

${ }_{44}$ Sobre esta supuesta traducción véase Ashtor, The Jews of Moslem Spain, Vol. I, pp. 364-365, n. 12.

${ }^{45}$ Abraham ibn Daud, Sefer ha-Qabbalah, p. 49 de la edición.

${ }^{46}$ Por ejemplo, el permiso de qasāma emitido por al-Ḥakam II para el judío al-Ḥağğāăğ b. al-Mutawakkil que le permitió controlar todos los casos de herencia de Lucena (Ibn Hayyān, Anales palatinos, p. 189).

${ }^{47}$ Entre sus medidas más populares, según Ibn 'Id dārī, el califa al-Ḥakam II en el año 967 designó "maestros destinados a enseñar el Corán a los hijos de los enfermos y de los pobres de los alrededores de la mezquita y en todos los arrabales de Córdoba. Asignó sueldos a dichos maestros y en su anhelo de complacer a Dios les instó a que pusiesen en la 
la política de la corte, se incrementó el interés por la producción y adquisición de obras. Para este entonces es muy posible que Hayyūğ hubiese redactado ya su obra mayor, asentando los principios de la filología hebrea que siguen vigentes hasta hoy día y que por tanto el conocimiento del hebreo bíblico en al-Andalus hubiese alcanzado para entonces la supremacía en todo el Mediterráneo. La propia biblioteca del califa va a contar con casi medio millón de volúmenes y van apareciendo las grandes bibliotecas; en el caso de la comunidad judía destaca sobre todas la de los Banū Nagrela, ${ }^{48}$ el propio Šĕmu'el b. Nagrela reconoce antes de asentarse en Granada que conserva y custodia el manuscrito autógrafo del célebre tratado de Ḥayyūğg. ${ }^{49}$ También Ibn Ğanāh da testimonio en sus primeras obras (alrededor del año 1013) del uso de rollos levantinos para contrastar las diferentes lecturas bíblicas y que en todo caso llegarían a Córdoba durante el reinado de al-Ḥakam II. ${ }^{50}$ Finalmente, este período va a destacar por la proliferación de copistas y es muy posible que ocurriese otro tanto en la comunidad judía. ${ }^{51}$ Los delegados para la adquisición de libros pueden ser ahora incluso familiares que por motivos comerciales tienen la oportunidad de visitar otros países y en sus ratos de ocio dedicarse al estudio. ${ }^{52}$

docencia sus más sinceros esfuerzos. De esas escuelas estableció tres en torno a la mezquita Aljama y veinticuatro en los arrabales de la ciudad" (Ibn 'Id̄ārī al-Marrāqušì, Kitāb albayān al-mugrib, p. 241).

48 Abraham ibn Daud, Sefer ha-Qabbalah afirma que dicha biblioteca fue saqueada tras la matanza de judíos acaecida en Granada en el año 1066 (p. 57 de la edición) y que Yiṣhaq ibn Balya (1035-1094) intentó reunir de nuevo la biblioteca de Ibn Nagrela en Sevilla (pp. 59-60 de la edición).

${ }^{49}$ Los autores de la colección Rasā'il al-rifāa afirman en la segunda parte de la primera epístola contra el gramático Ibn Ğanāḥ wa- 'alā anna 'indanā fì l-nusha allatī bi-ḩațt yadi-hi nuho 'eden... 'Sin embargo lo que nosotros encontramos en su copia autógrafa ¡descanse en paz!...' (Firk II 1239: 6r:1-2 y en grafía árabe por Derenbourg - Derenbourg, Opuscules et traites d'Abou'l-Walid, p. LXIII).

${ }^{50}$ Derenbourg - Derenbourg, Opuscules et traites d'Abou'l-Walid, pp. 71 y 193.

51 'Īsā, Tärīh al-ta' 'ìm fì l-Andalus, p. 138.

52 Así en el Kitāb al-mustalhaq de Ibn Ğanāḥ (Derenbourg - Derenbourg, Opuscules et traites d'Abou'l-Walid, p. 147): "Mi primo (en el manuscrito original אבן נומי y así Derenbourg p. 147; se trata claramente de un error del copista que descompuso la letra 'ayin אבץ/בן עמי אu nun-waw tal y como confirman dos copias de la colección Firkovich que leen y la versión hebrea, véase Téné, Sefer ha-hassagah, p. 146 n. 108) me ha contado que ha visto en Egipto en una copia del Kitāb hurüuf al-līn (de Ḥayyūğ) notas corruptas que se habían añadido a esta como si fuesen del propio autor y que no son otra cosa que reflexiones de algunos andalusíes que conozco bien; me mostró un puñado que había anotado para sí mismo porque las desaprobaba". 
El último gran califa de la Córdoba omeya, Hišam II (976-1009), hereda el trono siendo aun muy joven y toma las riendas del estado Almanzor (977-1002), fundador de la dinastía 'amirī. Almanzor ya no tendrá esa afabilidad de los califas anteriores para con los judíos, ${ }^{53}$ sino que se preocupará más por la fiscalidad del estado que por su desarrollo cultural y así, fundará un nuevo complejo palatino y administrativo conocido como Madīnat al-Zāhirah (979-1009) y nombrará naśí’ a un sedero, Ya‘ăqob b. Ğaw que tras negarse a aplicar cierta política fiscal a la comunidad judía, posiblemente abusiva, fue encarcelado en la prisión de complejo Madīnat al-Zahrā' que había sido desmantelado y donde se mantenía recluido al califa Hišam II; este, siguiendo la política de favoritismo de su familia hacia los judíos, lo liberará de la cárcel nada más percatarse de su presencia. ${ }^{54}$

Durante su regencia, Almanzor destacó por reprimir la filosofía, la lógica y la astrología pero también pretendió emular a los califas. ${ }^{55}$ Así, por ejemplo, aplicó políticas que estimulasen la creación artística, específicamente la poesía, llegando a crear un dīwān o "ministerio de poetas" y es precisamente en esta época cuando encontramos a una pléyade de célebres poetas hebreos cordobeses tales como ha-Kohen b. al-Muḍarram, ${ }^{56}$ Abū Zakariyā' Yahyā b. Hanīgāa,${ }^{57}$ Yosef ibn Abitur ${ }^{58}$ y el importantísimo Yiṣhaq b. Halfūn. ${ }^{59}$

Almanzor continúa fomentando la inmigración de orientales y es muy posible que la llegada de sus mercenarios bereberes invitase a más judíos magrebíes a asentarse en Córdoba. ${ }^{60}$ Pero de todas sus políticas de mecenazgo, hay que destacar la creación de una tertulia semanal en

${ }^{53}$ La relación de Almanzor con los judíos apenas ha dejado apuntes positivos, de hecho Ibn 'Idārī cuenta "que uno de los visires de Almanzor vio en sueños a un judío que iba por las calles de az-Zāhira con unas alforjas al hombro y que gritaba 'jarrubiš, jarrubiš'; preguntó a un intérprete [de sueños] acerca de aquello y le notificó la proximidad de su ruina” (Maíllo Salgado, La caída del Califato de Córdoba, p. 67).

${ }^{54}$ Abraham ibn Daud, Sefer ha-Qabbalah, p. 52 de la edición. Para los Banū Ğaw véase Ashtor, The Jews of Moslem Spain, vol. I, pp. 376-377.

55 'İsā, Tārīh al-ta 'lìm fì l-Andalus, p. 143-153.

${ }_{56}$ Mošeh ibn 'Ezra, Kitāb al-muhāọdara wal-mud̄ākara f. 31r

${ }^{57}$ Mošeh ibn 'Ezra, Kitāb al-muḥạdara wal-mud̄äkara f. 31r; Schirmann, The History of Hebrew Poetry, pp. 145-146.

58 Targarona Borrás, "Breves notas sobre Yosef ibn Abitur"; Schirmann, The History of Hebrew Poetry, pp. 150-173.

${ }^{59}$ Cano, Yișhaq ibn Jalfun. Poeta cortesano cordobés; Schirmann, The History of Hebrew Poetry, pp. 173-182.

${ }^{60}$ Véase Ashtor, The Jews of Moslem Spain, vol. I, pp. 381-382. 
la que incluso él mismo examinaba en persona a los tertulianos. ${ }^{61} \mathrm{Su}$ hijo, al-Muzzafar (1002-1009) continuará su política a grandes rasgos. ${ }^{62}$ A su muerte, su hermano, 'Abd al-Raḥmān Sanchuelo, no sabrá mantener las riendas del estado y conducirá a la ciudad a una situación de guerra civil que se prolongará durante años. ${ }^{63}$

Este conflicto, denominado por los andalusíes como al-fitna al-barbariya se prolongó en el tiempo (1009-1031) y supuso el desmoronamiento y desintegración de la institución califal en al-Andalus. Es un conflicto que afecta a toda la población cordobesa por igual, indistintamente de su clase o condición social, por lo que los judíos lo sufren en primera persona como el resto de los ciudadanos. No sabemos el grado de implicación de las capas más humildes de la sociedad judía en el asalto al alcázar por la turba liderada por el omeya Muhammad II al-Mahdī en 1009. Este conflicto tuvo eco incluso en las comunidades judías del resto del mundo árabe $\mathrm{y}$, así, se conserva, maltrecha, una carta del año 1012 en la genizah de El Cairo ${ }^{64}$ enviada por Musā b. alMağğānī, residente permanente en Fustat, al comerciante judío Abū 1Farağ Yosef b. Ya'ăqob [b. 'Awkal] en la que da testimonio del intenso sufrimiento de la población cordobesa y de la destrucción causada durante la contienda. En la carta se menciona a los eslavos que han tomado el control de la ciudad de Córdoba en nombre del califa Hišām II y dice explícitamente que los cordobeses, a pesar de las circunstancias, prefieren morir que someterse a la dominación bereber.

En todo caso los judíos van a estar presentes en la primera línea de la contienda, bien de forma pasiva, como el caso del cadáver de un judío que dada su similitud física con el califa Hišām II fue mostrado públicamente por Muhammad II $a l-M a h d \bar{\imath}$ en 1009 para certificar la muerte del soberano; ${ }^{65}$ bien de forma activa, como el caso de un judío, "visir de los francos", muerto en combate a manos de los bereberes que hallaron en su tienda treinta mil dinares. ${ }^{66}$

61 'Īsā, Tārīh al-ta 'lìm fì l-Andalus, p. 148.

${ }^{62}$ Véase Ashtor, The Jews of Moslem Spain, vol. II, p. 8, n. 12.

${ }^{63}$ Maíllo Salgado, La caída del Califato de Córdoba; para una descripción detallada de los antecedentes que conducen a esta situación véase Rosado Llamas, La dinastía hammudi y el califato, pp. 57-98.

${ }_{64}$ T-S 12.218. Véase la edición de Gil, In the Kingdom of Ishmael, vol. II, pp. 328-321.

${ }_{65}$ Maíllo Salgado, La caída del Califato de Córdoba, p. 76.

${ }^{66}$ Maíllo Salgado, La caída del Califato de Córdoba, p. 91. 
En abril de 1013 se produjo el enfrentamiento final entre cordobeses y bereberes, haciéndose los últimos con la victoria. Comenzó el saqueo de la ciudad y los cordobeses tuvieron que emplear todo el dinero que les quedaba para conseguir el amán. Sulaymān I volvió a ser nombrado califa por segunda vez y Hišām II desapareció para siempre. Una vez conquistada Córdoba, Habbūs b. Māksan, uno de los caudillos bereberes y futuro rey de la taifa de Granada, localizó los huesos de su hermano escondidos en la casa de su asesino. Al comprobar que había sido devorado, retiró el amán a los cordobeses y comenzó una siega sin precedentes provocando el éxodo masivo de la población y el reparto de la ciudad entre los bereberes. ${ }^{67}$ Las fuentes posteriores, tanto islámicas como judías, mantienen que la población huyó (haraba katīr minhum, según Ibn 'Id̄ārīi ${ }^{78}$ y barḥu según Abraham ben Daud). ${ }^{69}$ Sin embargo, los testigos oculares de la contienda prefieren hablar de exilio; es el caso de Ibn Hazm que incluso data este evento el día 19 de julio de 1013 y emplea la voz uğlinna para referirse a su exilio, ${ }^{70}$ la misma usada por Ibn Ğanāḥ ( ğalā'). ${ }^{71}$ No sólo eso, sino que el propio Ibn Ğanāḥ parece confirmar que el exilio fue programado y la gente distribuida por regiones al decir "cuando Dios decretó nuestro exilio de Córdoba hacia Zaragoza debido a los disturbios (al-fitan) que estallaron en ella, el que me había preguntado estaba en el grupo de exiliados a Zaragoza"; 72 y así deben entenderse las distribuciones a las que alude Abraham ibn Daud en su Sefer ha-Qabbalah: ${ }^{73}$ "algunos se fueron a Zaragoza, donde sus descendientes permanecen hasta la actualidad, mientras que otros se fueron a Toledo, donde sus descendientes han conservado su iden-

${ }^{67}$ Maíllo Salgado, La caída del Califato de Córdoba, p. 104.

${ }^{68}$ Lévi-Provençal, al-Bayān al mugrib, p.115.

${ }^{69}$ Abraham ibn Daud, Sefer ha-Qabbalah p. 72 de la traducción y 53-54 de la edición.

${ }^{70}$ Pétrof, Ab̂̂-Muhammed-Alî-ibn-Hazm al-Andalusi, Tauk-al-hamâma, p. 124.

${ }^{71}$ Derenbourg et Derenbourg, Opuscules et traités d'Abou'l-Walid, p. 3. De Ibn Hazm parece tomar el dato el historiador Dozy cuando dice: "Quant aux Berbers, ils s'établirent d'abord à Secunda; mais trois mois après, tous les habitants de Cordoue, à l'exception de ceux qui demeuraient dans le faubourg oriental et dans le quartier qui s'appelait la cité, furent frappés d'une sentence d'exil, et leurs biens furent confisqués au profit des vainqueurs, qui occupèrent alors les maisons qui avaient échappé à l'incendie" (Dozy, Histoire des Musulmans d'Espagne, pp. 310-311). Y así le sigue Asín Palacios, Abenházam de Córdoba, Tomo I, pp. 72-73.

${ }^{72}$ Derenbourg, Livre des parterres fleuris, p. 304.

73 Abraham ibn Daud, Sefer ha-Qabbalah p. 72 de la traducción y 53-54 de la edición. 
tidad hasta el presente. Por su parte, este R. Samuel [ha-Nagid], huyó a Málaga...".

Los estragos de la guerra y el colapso económico de la capital del califato se van a hacer sentir en el patrimonio material de la comunidad, como el caso del mobiliario de la sinagoga donde, según las fuentes, el juez Hanok b. Mošeh sufrió un grave accidente al romperse el almimbar que por su estado no pudo soportar el peso de tres adultos el día de Simhat Torah de 4775 (septiembre de 1014); el juez se rompió la cadera y falleció a los pocos días. ${ }^{74}$

\section{Etapas educativas}

Pero además de las políticas de mecenazgo, también nos ayudan a entender el grado de integración y la educación de los judíos del califato de Córdoba las distintas etapas educativas de la época. ${ }^{75}$ Las fuentes apenas nos dan información de este período sobre las escuelas primarias judías, a las que acudían los niños a partir de los seis años y hasta los trece o catorce para aprender el texto revelado (seguro la Biblia hebrea pero algunos niños también el Corán), lecto-escritura (la lectura del hebreo es preceptiva para el desarrollo del oficio sinagogal) y alguna otra asignatura, bien en casa, bien en una escuela o incluso patio, dependiendo del poder adquisitivo de la familia.

Sí tenemos más datos sobre la educación secundaria que proporcionaba una sólida formación y daba acceso a un trabajo o incluso, si se daba el caso, a una tercera fase de especialización. Comenzaba a partir de los catorce años y podía prolongarse durante una década. Las lecciones magistrales eran públicas, organizadas por un maestro alrededor del cual se formaba un corro que tomaba su nombre. Esta fase de la enseñanza se basaba en la memorización y esta se llevaba a cabo a través de la lectura (iqrā') y los dictados $\left(i m l \bar{a}^{\prime}\right){ }^{76}$

En la Genizah de El Cairo pueden encontrarse hojas sueltas dedicadas a un mismo tema pero que por el recto contienen pasajes de una

${ }^{74}$ Abraham ibn Daud, Sefer ha-Qabbalah p. 53. No parece por tanto que el mobiliario no fuese renovado por la aplicación estricta del pacto de Omar.

${ }^{75}$ Para la siguiente descripción me baso en el estudio de 'İsā, Tārīh al-ta 'lìm fì l-Andalus, pp. 215-414.

76 'İsā, Tārīh al-ta 'Tìm fì l-Andalus, pp. 347-349. 
obra y por el verso de otra; parecen claramente pasajes de obras copiadas al dictado de un maestro. ${ }^{77}$ Las fuentes nos dejan tanto testimonios directos como indirectos de la lectura comentada de obras de referencia (iqrā') con maestros.

Así, las fuentes confirman que la llegada de Mošeh b. Hanok a Córdoba, su nombramiento como juez de la comunidad y sus conocimientos van a provocar que muchísima gente se traslade a la capital desde al-Andalus y el Magreb para estudiar (liqrot) con él, ${ }^{78}$ flujo apoyado además por la política migratoria del califato.

La misma sensación de lectura revisada queda en las obras filológicas redactadas en la época, por ejemplo, en los excursos del Maḥberet de Mĕnahem b. Saruq. ${ }^{79}$ Estas digresiones, en forma de información complementaria, bien pueden ser de carácter didáctico, exegético o incluso polémico. Las primeras son de naturaleza gramatical (especialmente morfológica) o lexicográfica; las segundas ayudan a entender algún pasaje oscuro o ambiguo del texto bíblico; mientras que las últimas son claramente una revisión de las obras que ya habían llegado a Córdoba para entonces gracias a la política de importación de libros, como ya se ha visto. Měnahem b. Saruq es muy duro con los exegetas orientales (sabora'im y anše pitron), los compositores de poesía sinagogal palestinense ${ }^{80}$ con una obra hoy perdida de Yěhudah ibn Qurayš de Tahart ${ }^{81}$ e incluso con el Egron de Să'adya Ga'on. ${ }^{82}$

Otro tanto puede decirse de la célebre obra de Hayyūğ, Kitāb alaf'āl dawāt hurüf al-lìn wa-l-madd 'Libro de verbos con letras débiles y de alargamiento' y Kitāb al-af'âl dawāt al-mițlaȳ̄n 'Libro de verbos con geminadas'. Es, con diferencia, uno de los libros más leídos y estudiados en la Edad Media, tal y como confirma el acopio de fragmentos conservados en las colecciones: sesenta y cinco fragmentos en Reino Unido (de los cuales cincuenta y seis pertenecen a la colección Taylor-Schechter de la Universidad de Cambridge), dieciocho en Es-

77 Véanse por ejemplo los especímenes de la colección Taylor-Schechter AS 140.13 y NS 301.69 que parecen claramente apuntes de un maestro dictando, entre otras, la obra de Ḥayyūğ.

${ }^{78}$ Abraham ibn Daud, Sefer ha-Qabbalah p. 48.

79 Sáenz-Badillos, Mahberet Měnahem, pp. 25-36.

${ }^{80}$ Sobre la lengua de esta poesía véase Sáenz-Badillos, Historia de la lengua hebrea, pp. 209-214.

81 Véase la nota 39.

82 Véase la nota 38. 
tados Unidos (colección de The Jewish Theological Seminary of America), más uno en Berlín que se une a una copia de la colección Firkovich, donde se custodian nada menos que noventa y seis fragmentos que pertenecieron como mínimo a ochenta copias distintas. Semejante acopio de testimonios nos muestra hasta tres grandes familias textuales que nos ayudan a entender el proceso de estudio y trasmisión de la obra: la copia autógrafa, de la que sólo se conserva una copia completa de Kitāb al-af' āl d dawāt al-mitlayīn 'Libro de verbos con geminadas' datada en 1120 y que afirma ser copia del autógrafo en la colección Firkovich; la versión estándar que ha perdido la vocalización masorética y ha sufrido todo tipo de adiciones y omisiones a manos de los usuarios, copistas y maestros, es la más numerosa y compleja; y una tercera y última versión que incluye las glosas de Ibn Ğanāḥ y que se conserva en dos copias de la colección Firkovich. En definitiva, la obra se configuró como el clásico de referencia durante la educación secundaria y así se estuvo copiando y estudiando ininterrumpidamente en el mundo arabófono desde el siglo $\mathrm{x}$ hasta el siglo XV, dando testimonio de la supremacía de la escuela andalusí en materia filológica.

Según Mošeh ibn 'Ezra, Hayyūğ y sus seguidores ( $\left.\check{s}^{\prime} \bar{l} ' a h\right)$ introdujeron en el organon judío las ciencias especulativas y racionales ( $a l$ 'ulüm al-nazariya wa-l-ma 'árif al-'aqliya) ${ }^{83}$ Efectivamente, el método de Hayyūğ es demostrativo (muktasab) y se basa en la especulación racional fundamentada en la analogía (qiyās). ${ }^{84}$ Así, en un primer momento se lleva a cabo la descripción de conceptos básicos, seguido de generalizaciones que universalizan las teorías. A continuación, se desarrollan las reflexiones y especulaciones necesarias para explicar di-

${ }^{83}$ Mošeh ibn 'Ezra, Kitāb al-muhạdara wa-l-mudākara f. 30. Para el proceso de arabización de los estudios de la lengua hebrea en al-Andalus véase Martínez Delgado, "The Arabicization of the Hebrew morphology in al-Andalus". Para la descripción de estas ciencias entre los caraítas véase Mohamed, "La epistemología de al-Qirqisānī y su vinculación con el kalām islámico".

${ }^{84}$ El recurso analógico se concebía en los estudios árabes medievales como un instrumento o método que permitía justificar la estructura y la naturaleza de la lengua, además de probar o demostrar su conformidad con los planteamientos de la razón, de ahí su universalización. En la práctica, el uso de la analogía llevaba al gramático a buscar las causas que justificaban el aspecto físico de cada uno de los componentes del edificio lingüístico y a demostrar, a continuación, que la forma, por rara que parezca, sigue adecuadamente los cauces de los principios naturales que rigen a la lengua; el gramático Ibn Ğinnī desarrolla magistralmente este concepto desde un punto de vista lingüístico en al-Hașa 'is, Vol. I, pp. 113 y 300$)$. 
chas generalizaciones. Acabado este proceso, pueden catalogarse los diferentes géneros que componen el espectro verbal hebreo y las supuestas anomalías pasan a ser formas totalmente regulares en su entorno.$^{85}$ Esto permite a Ḥayyūğ reconocer hasta cinco géneros o tipos de raíces trilíteras en el sistema verbal hebreo: los verbos sanos, los de primera radical débil, los de segunda radical débil, los de tercera radical débil y los geminados. ${ }^{86}$ Este gran y cómodo árbol de sólo cinco ramas enormes revolucionó la historia de la lengua hebrea y de hecho aparece, más o menos transformado, en todos los métodos de estudio de la lengua de la Biblia hasta hoy. Cada rama, o género aristotélico, acogerá aquellas raíces que compartan la característica que las hace idénticas entre sí pero diferentes al resto de las raíces. Fue entonces cuando se establecieron las reglas de la morfología, ya que la búsqueda, reconocimiento y división de los morfemas radicales y funcionales dentro de una misma voz o forma suscitó los más dispares métodos durante todo el siglo $\mathrm{X}$, no aceptándose de manera universal ( $\left(\check{g} m \bar{a}{ }^{\circ}\right)$ ninguno de ellos hasta la aparición de la obra de Ḥayyūğ,${ }^{87}$ donde las teorías morfológicas aparecen recogidas en las introducciones gramaticales a los cuatro diccionarios de sus tratados y la lectura de cada una de ellas es obligada para entender lo que viene a continuación. Una vez se ha identificado la raíz por deducción analógica, se lleva a cabo la identificación del género al que pertenece. A continuación, se buscan, en teoría, todos los individuos, o formas, que aparecen registrados en la Biblia con esa raíz y, tras ser sometidos a un minucioso análisis morfológico, se catalogan por especies, que son las acepciones. El resultado de la búsqueda y catalogación aparecerá recogido en los diccionarios que cierran los capítulos de los Kutub al-'af'äl o Libros de verbos.

Este método analógico conlleva o supone la existencia de una forma pura u original $(a s ̣ l)$ y de una resultante o explícita ( $\breve{s} a h s s$ ), por lo tanto, cuando ambas no coincidan, habrá que buscar la causa que explique el

${ }^{85}$ Inspirado en métodos clásicos como los descritos por Lameer, Al-Fārāāi and Aristotelian Syllogistics, p. 198.

${ }^{86}$ Los verbos de primera radical nun no son un género específico en la división de Hayyūğ, pues el fenómeno que los caracteriza también se da en todas las formas nif'al, es decir, es una característica de la consonante, no de los verbos y de ahí que no los incluya como un género en sus tratados.

${ }^{87}$ Véase el modelo de los caraítas en Vidro, Verbal Morphology in the Karaite Treatise on Hebrew Grammar. 
aspecto del individuo explícito, o šahs, en su origen, o aṣl. Con todo, se puede invertir la situación y buscar las causas que expliquen un așl determinado mediante las de un $\check{s} a h s .^{88}$ Además, parte del éxito de Ḥyyūğ radica en que su obra aparecen una serie de conceptos que en su momento resultaban claros y obvios a la gente culta que conocía o había estudiado el árabe y de ahí la tremenda difusión que alcanzó el Libro en su época. ${ }^{89}$

Además de ser una obra de referencia, la obra de Ḥayyūğ tiene otro nivel muy poco conocido y estudiado, que incluso pasaba desapercibido a muchos de sus usuarios de la época, y es que desde la primera página se configura como una lectura revisada del Maḩberet de Mĕnahem b. Saruq $;{ }^{90}$ de hecho, es casi un complemento a este diccionario y viene a completar su carencia en el campo de la morfología del sistema verbal del hebreo bíblico, específicamente el caso de los verbos débiles y geminados. El hecho de que el autor mantenga en el anonimato a todas las fuentes que revisa ayudó sin duda a establecer una especie de kilómetro cero para el estudio de la lengua hebrea no sólo en al-Andalus sino en todo el mediterráneo medieval.

Otro tanto puede decirse de su otra obra, Kitāb al-nutaf 'Libro de los manojos'. ${ }^{91}$ Dispuesto como un comentario exegético-filológico a los ocho libros proféticos de la Biblia hebrea en realidad nos muestra la aplicación práctica de los anteriores tratados a la lectura del texto bíblico. En todo caso, ambas obras nos muestran la práctica y el modelo docente del hebreo bíblico en la Córdoba califal y se consolidan como

${ }^{88}$ Así, si todos los verbos están compuestos por tres radicales, como KaTaB, en el caso de $Q a M$ una de sus radicales se ha transformado o escondido. QaM es el individuo o forma explícita mientras que su forma original, o așl, puede ser Qa'aM, QaYaM o QaWaM. Estas formas originales resultaron cacofónicas en algún momento pretérito a los hablantes, por lo que las alteraron para facilitar su pronunciación, de hecho, en ocasiones, la grafía puede mostrar la radical transformada, en su versión fosilizada, como en el caso de wě$Q a^{\prime} M$ (Oseas 10,14). Esta forma original puede explicarse, además, desde el individuo explícito, tal y como aparece lě-QaYYeM (Ester 9,31).

${ }^{89} \mathrm{La}$ terminología empleada por Ḥayyūğ demuestra que se inspiró en el método ideado por los sabios gramáticos musulmanes, posiblemente en la versión mixta desarrollada en Bagdad desde el siglo X. Esta escuela había aceptado el uso del qiyās, o analogía, establecido por los gramáticos de Basora ya en el siglo VIII y véase Versteegh, "The Origin of the Term qiyās in Arabic Grammar".

${ }^{90}$ Sobre este aspecto véase Martínez Delgado, "El uso del Maḥberet entre los principales filólogos hebreos".

${ }_{91}$ Basal, Kitāb al-nutaf lě-rabī Yěhudah Hayyūğ; Maman - Ben-Porat, Kitāb al-nutaf. 
modelo para futuras obras, análisis y comentarios exegéticos de marcado carácter andalusí.

El autor que más datos nos ofrece sobre su formación es Ibn Ğanāḥ, del que gracias a las fuentes sabemos que se formó en las tres grandes ramas que configuraban esta formación secundaria: ciencias religiosas (exégesis y textos tradicionales judíos), lingüísticas (la obra de Ḥayyūğ y de los principales gramáticos árabes) y de la razón (con seguridad lógica y botánica).

Durante su formación secundaria en Córdoba, Ibn Ğanāḥ indica que estaba plenamente integrado en el célebre círculo de drogueros y botánicos cordobeses, teniendo incluso acceso a uno de los jardines privados de la residencia del visir Ibn Šuhayd donde pudo examinar ocularmente la planta conocida como al-māš ya que no podía encontrarse en ningún otro rincón de Córdoba. Ibn Šuhayd, en una clara muestra de gentileza, le informó que Ibn Hasday, el judío, se la había traído del Este. ${ }^{92}$ Debe tratarse sin duda del célebre visir y gobernador de Almanzor (9761009), Abū Marwān (nieto) ibn Šuhayd (935-1003) y padre del famoso poeta Abū 'Āmir ibn Šuhayd (992-1035); en cuanto a Ibn Hasday, ${ }^{93}$ debe tratarse de uno de los hijos de Ibn Šaprut, bien Abū l-Walīd Hasday que se asentará en Lucena durante la fitna, bien Abū 'Amr Yūsuf que volverá a reencontrarse en Zaragoza con Ibn Ğanāḥ.

En Córdoba, Ibn Ğanāḥ se especializó en farmacopea con maestros de la talla de Sulaymān ibn Ğulğul, ${ }^{94}$ médico personal del califa Hišām II que falleció a partir del año $994 / 5 .{ }^{95}$ Con él, leía su obra sobre drogas: ${ }^{96}$

Ibn Ğulğul dijo en su Risāla fì l- 'Aqāqīr 'Tratado sobre Drogas' que no se conoce un nombre vernáculo para qāqullā. Cuando yo estudié (qirāa 'atī) este tratado con él me dijo que se trata de $b^{\prime} \underline{d} b l y l h\left({ }^{*} b \bar{a} \underline{d} a\right.$ bullīluh).

92 Bos - Kas, "Arabic Pharmacognostic Literature and Its Jewish Antecedents", pp. 197-198. Fenton “Jonah Ibn Ganāḥ̣'s Medical Dictionary”, p. 130. Ibn Šuhayd tuvo al menos dos residencias en Córdoba, la almunia del arrabal de al-Mugīra primero y más tarde, y a petición de Almanzor, se trasladó al palacio de Ibn al-Nu'mān en el complejo palatino de la dinastía amirí al-madīna al-zāhira (979-1009).

${ }_{93}$ Sobre esta familia véase Stroumsa, "Between Acculturation and Conversion in Islamic Spain".

94 Bos-Käs, “Arabic Pharmacognostic Literature”, p. 148. Sobre Ibn Ğulğul véase Dietrich, "Ibn Djuldjul” e Garijo-Galán "[1396] Ibn Ŷulŷul".

${ }^{95}$ Garijo Galán "Ibn Ŷulŷul”, pp. 163-166.

96 Bos-Käs, “Arabic Pharmacognostic Literature”, p. 148. 
Este modelo de lectura comentada de una obra, bien propia bien ajena, es precisamente el formato que encontramos en la obra de Ibn Ğanāh titulada Risālat al-taqrīb wa-l-tashīl donde se reproducen pasajes de la obra de Ḥayyūğ (por medio de la fórmula qāla Abū Zakariyā' 'dijo Abū Zakariyā') y comentados por Ibn Ğanāḥ (por medio de la fórmula qāla al-mufassir 'dijo el comentarista'). Los contenidos del tratado nos muestran las dificultades reales con las que se encontraban los estudiantes iniciados a la hora de enfrentarse a la obra mayor de Hayyūğ, específicamente en aquellos casos donde las lenguas árabe y hebrea no compartían usos comunes en lo que se refiere a la ortografía de las letras débiles y de alargamiento. ${ }^{97}$

Todavía en Córdoba, Ibn Ğanāḥ tuvo la oportunidad de coincidir con el gran poeta Yișhaq b. Mar Ša'ul de Lucena, con el que estudió lengua hebrea, específicamente discutían sobre casos de los tratados de Hayyūğğ ${ }^{98}$ los poemas del propio ben Mar Ša’ul al que defendía cuando correspondía, ${ }^{99}$ por lo que es muy posible que sus versos de ju-

97 Alahmad Alkhalaf y Martínez Delgado, Risālat al-taqrīb wa-l-tashīl, pp. 17-20.

98 Derenbourg, Livre des parterres fleuris, p. 269 donde se discute la obra de Hayyūğ y así lo repite en Kitāb al-taqrīb wa-l-tashīl (ed. Alahmad Alkhalaf y Martínez Delgado, 141r-v de la edición y 133 de la traducción).

99 "Has de saber que no podemos prohibir al poeta que altere la forma del paradigma พx cuando se anexiona a un nombre absoluto ya que hemos encontrado esta forma alterada por distintos pasajes de la Biblia cuando se anexiona a nombres absolutos tal y como hemos mencionado previamente y siguiendo esta tendencia dijo Yișhaq b. Mar Ša'ul,

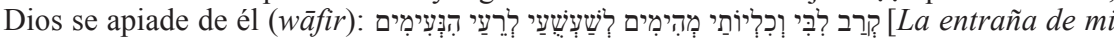
corazón y mis riñones se alborotan / por mis deleites, mis agradables compañeros]. Ane-

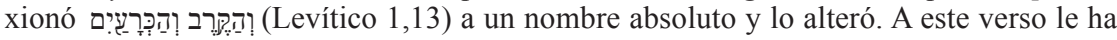
ocurrido algo simpático que carece de malicia, que te voy a reseñar, y es que la mayoría de los rapsodas transmiten ọג לִּר (la membrana de mi corazón), así se encuentra en la mayoría de las copias y así lo transmitía yo mismo a partir de otro. Cuando leí este poema

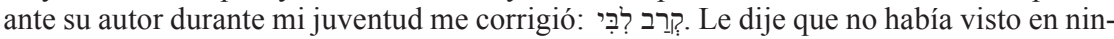

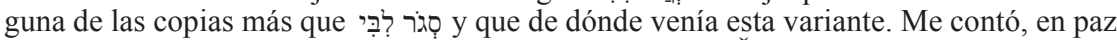
descanse, que estaba elogiando en este poema a Jacob [b. Ğaw?] y a su hijo, los anfitriones, en paz descansen, y que se lo envió desde su ciudad a Córdoba llegando al homenajeado. Abū Zakariyā' b. Ḥaniga' y Abū Ibrahīm b. Halfūn [estaban con él] y les resultaba

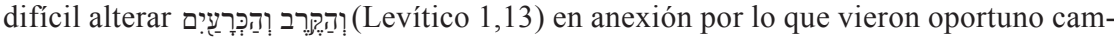
biar la expresión por ọ̣, por reconciliación pero desbaratando el significado original. Dijo: en Córdoba ya se copió el poema con esta alteración y sustitución. Me contó Abū Ibrahīm b. Sahl al-Talmasānī, en paz descanse, que en Egipto vio a lingüistas que también desaprobaban a este poeta por decir esto y pensaron que lo había dicho teniendo en mente

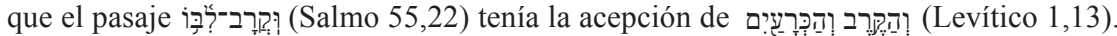
Sin embargo, el poeta está libre de todas las injurias que se han vertido contra él" (Derenbourg, Livre des parterres fleuris, pp. 207-208). 
ventud los compusiese bajo la supervisión de ben Mar Ša'ul; ${ }^{100}$ pero igual que lo defendía, también lo corregía. ${ }^{101}$ También atendió lecciones magistrales de Yiṣhaq b. Ğiqațela, maestro de la primera generación (década de los cincuenta y sesenta del siglo x) al que denomina alšayh,${ }^{102}$ y de Abū l-Walīd b. Hasday; ${ }^{103}$ generalmente son apuntes que tratan sobre cuestiones de morfología que siempre giran en torno al libro de Ḥayyūğ.

Aun en Córdoba debió de destacar ya como filólogo de la lengua hebrea, quizá hubiese completado ya su formación secundaria o estaba a punto y de ahí que un amigo le pidiese que recopilase todas esas anotaciones, observaciones y comentarios que tenía sobre la obra de Ḥayyūğ y que se convertirían más tarde en el célebre Kitāb al-mus-

100 "Más infame aún si cabe es el livor que sufrí por parte de los envidiosos y sus ansias de calumniarme: sabéis bien que la poesía no está entre mis habilidades ni el poema entre mis productos, no estoy relacionado con ella ni la conozco y tampoco considero que sea algo que temer o escatimar sino que me siento por encima de ella y superior a su discurso si bien es cierto que durante la juventud compuse piezas que conservamos sabiendo que son obra mía; pero la envidia se apoderó de un grupo de gente que recogió una de estas piezas, que era idónea, en un libro, se la atribuyeron a Ibn Hुalfün, el poeta, y se la enviaron a gente de Toledo. Me contó uno de los discípulos, consciente de que el poema era mío, que se juntó un día en Toledo con personas que estaban leyendo dicho poema y se lo atribuían al susodicho poeta mencionado, él les dijo "este es de fulano", refiriéndoseme a mí, "y nosotros damos fe de que él lo compuso y que de él lo tomamos" pero no le hicieron caso alguno" (Derenbourg, Livre des parterres fleuris, pp. 304-305). Este apunte le costó el reproche posterior de Mošeh b. 'Ezra, Kitāb al-muhạdara wa-l-mud̄ākara f. 74: "Abū l-Walīd (Ibn Ganāḥ) menciona en su obra mayor que tenía piezas poéticas pero que por envidia hacía él, le fueron atribuidas a Ben Halfün, el poeta; hubiera sido más apropiado a su rango que se hubiese abstenido de mencionarlo, pues los que como él merecen alta consideración y buena fama no necesitan de esta categoría menor del saber". Sobre este pasaje véase Abramson, "“Al pĕrat eḥad bĕ-ḥayye R. Y. ben Ğanāḥ”.

101 Derenbourg, Livre des parterres fleuris, p. 178.

102 Dos veces en Kitāb al-Mustalhaq (Derenbourg et Derenbourg, Opuscules et traités d'Abou'l-Walid, pp. 91 y 104): "El sabio anciano Yiṣhaq b. Ğiqațila, nuestro maestro, en

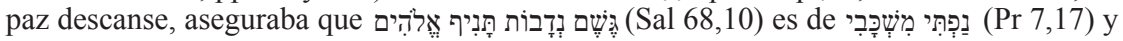
que en ambos casos debe interpretarse ‘irrigación'; de ser así, es su pesado" y “el anciano

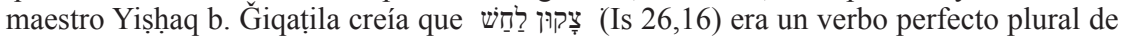
esta (raíz) adjunta (צוק). Su opinión era que nun en este caso estaba añadida, igual que se

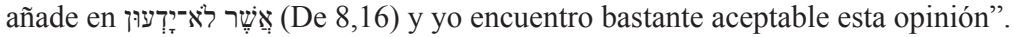

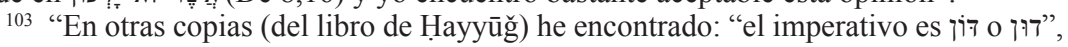
con ḥolem o šureq y esto es más afín con el original de Abū Zakariyā' (Hayyūğ), hasta que escuché al magnifico jefe y perfecto maestro Abū l-Walīd b. Hasdāy, en paz descanse, afïrmar que es posible que שִׁים (Jos 8,2) sea un imperativo del ligero y que (Ge 30,42) sea también su imperfecto, siendo esto posible en todos los verbos de la segunda radical defectiva por medio de la sustitución". Alahmad Alkhalaf - Martínez Delgado, Risālat altaqrīb wa-l-tashīl, p. 123 de la traducción. 
talhaq 'Libro anexo' (a los tratados de Ḥayyūğ); ${ }^{104}$ o que incluso la gente le interrogase sobre pasajes oscuros de la Escritura, según el mismo nos cuenta en su gramática Kitāb al-luma 'dejando claro que el que fue uno de sus maestros, Abū 1-Walīd b. Hasday, ya en Zaragoza, consideraba a Ibn Ğanāḥ toda una autoridad en la materia: ${ }^{105}$

\begin{abstract}
Voy a relatarte en este punto una anécdota que me ocurrió referente a esto con una persona de nuestro entorno íntimo. Dicha persona me preguntó en Córdoba por uno de los pasajes más oscuros del Libro; esta persona que me preguntó era uno de mis amigos. El pasaje en cuestión era uno de los que nadie que me precediese y de los que nos ha llegado prescripción alguna, hubiese resuelto. Cuando le expuse mi parecer sobre el pasaje, se levantó y me besó en la cabeza contentísimo por lo que la había expuesto. Cuando Dios decretó nuestro exilio de Córdoba hacia Zaragoza debido a los disturbios (al-fitan) que estallaron en ella, el que me había preguntado estaba en el grupo de exiliados a Zaragoza. Sucedió que tras muchos años llegó donde nosotros desde Córdoba Abū Yosef b. Ḥasdāy, Dios se apiade de él, me preguntó por este mismo pasaje y le sorprendí mucho y le hice muy feliz; me dijo: "Abū l-Walīd, por lo que hay entre nosotros, dime si has visto esta interpretación en otra persona que te precediese". Le contesté: "no, ni nadie que no sea yo ha dicho algo en absoluto". Al separarse de mí se encontró con el que me había preguntado la primera vez y le dijo para rivalizar con él: "Abū l-Walīd me ha alegrado el día sobremanera explicándome un pasaje bíblico de tal y tal modo con una interpretación portentosa que nadie había proferido antes que él y que es como sigue" y cuando comenzó a exponérsela se le adelantó (el otro) y la concluyó; dicha persona le dijo: "yo ya se la había oído a

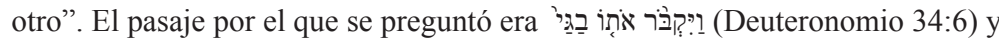

104 Así en la introducción del Kitāb al-Mustalhaq (Derenbourg y Derenbourg, Opuscules et traités d'Abou'l-Walid, pp. 1-3): "Querido hermano, amigo íntimo, Dios te resuelva las dudas y te revele los arcanos. No ha olvidado mi alma con el paso de tanto tiempo y todos estos años, que en nuestra tierra natal me pediste anexionase lo que se le pasó al ilustre maestro y perfecto príncipe, Abū Zakariyā', Hayyūğ, en paz descanse y reluzca su honor, completando los verbos con letras débiles y los verbos con geminadas... Lo que me ha retenido hasta este momento ha sido la superioridad de este hombre en esta disciplina, la majestuosidad de su control sobre ella y su dominio, pues nadie le precedió hablando de ella ni compitió con rival; y ha tenido para con nosotros un proceder oportuno, pues nos ha enriquecido con este arte, nos ha iluminado sus dificultades y nos ha ofrecido sus ausencias. Además, me ha dado pereza tomar mi decisión la expulsión que se ha decretado sobre nosotros, el vaivén y la emigración en la que estamos inmersos. Pero al haberme insistido tú, Dios te lo pague, y todos mis hermanos, que me han insistido contigo y que tienen por costumbre investigar y consultar, no he podido evitar atenderles y complacer sus deseos, por lo que he anexado en este tratado, en la medida de mis fuerzas y dentro de mis limitaciones, los géneros verbales, sus especies e individuos, que se dejó Abū Zakariyā'”"'

${ }^{105}$ Derenbourg, Livre des parterres fleuris, p. 304. 
por aquel entonces opinaba en este caso lo que te mencionaré en el artículo את de Kitâb al-ușūl y es algo en lo que tampoco nadie ha reparado antes que yo. Por su parte, (Ibn Nagrela,) el acosador que me contradice en las cuestiones de al-mustalhaq, ha atribuido parte de las curiosas interpretaciones que he presentado en esa obra a autores de oriente que nunca existieron.

La tercera etapa educativa era una fase de especialización profunda en la que el estudiante podía incluso trasladarse a otros lugares pero es, en todo caso, una fase complementaria de la segunda que se solía recibir en una madraza por parte de un $\breve{a} a h .{ }^{106}$ En la práctica, donde realmente se jugaban el prestigio durante esta etapa era en las tertulias tan del gusto de las capas cultas de la sociedad andalusí y en las que, después de haber recibido la iğâza o licencia (recompensa siempre de una extraordinaria memoria que casi todo el mundo poseía gracias al modelo educativo vigente entonces), uno recibía la verdadera sanción de los auténticos maestros porque allí, siguiendo a H. Pèrés, ${ }^{107}$ "les sarcasmes alors dégonflaient les réputations surfaites, l'admiration récompensait le talent ou le génie".

Tenemos constancia por escrito de estas tertulias desde la primera generación de sabios. Las primeras muestras nos llegan escritas en hebreo, es el caso de las Těšubot o Réplicas que originó el diccionario de Mĕnahem b. Saruq. Estos escritos bien pudieron ser redactados tras las tertulias organizadas por el propio Hasday b. Šaprut, tan sonadas que ha quedado testimonio de ellas incluso en las cabeceras de algunos poemas de la época. ${ }^{108}$ Dunaš b Labraț, que contaba con unos treinta años cuando se atrevió a descalificar a Měnaḥem b. Saruq, ${ }^{109}$ y Yěhudī b. Šešat no aportan nada nuevo, se centran en minucias lingüísticas y no suponen ningún avance en materia filológica. El mérito de Dunaš b La-

106 'Īsā, Tärīh al-ta 'līm fì l-Andalus, pp. 370-372.

107 Pèrés, La poésie andalouse en arabe classique au XIe siécle, p. 27.

108 Así en el manuscrito T-S 8K.15.8 se introduce el poema de Dunaš b. Labraț 'Me dice: no duermas' (ed. Schirmann, Ha-širah, vol. I, pp. 34-35; tr. Sáenz-Badillos y Targarona Borrás, Poetas hebreos de al-Andalus (siglos X-XII) Antología, p. 34) de la siguiente manera: d̄ālika wașfuhu fì mağlis Hasdāy al-săfardī 'esta es su descripción en una tertulia de Hasday el sefardí'. Hoy sabemos que el poema recogido bajo esa cabecera es en realidad un fragmento de un panegírico mucho más extenso y véase Elizur, "Hiddušim bě-ḥeqer ha-širah wě-ha-piyyut”".

109 Según Yěhudī b. Šešat: "Sus años son unos treinta, pero adultos y experimentados de sesenta ante él suelen aprender, por él son aconsejados y sus decisiones desean (Varela Moreno, Tešubot de Yehudi ben Šešet, p. 16). 
brat consistió en introducir sus críticas con un poema donde por primera vez se adaptaba la métrica árabe a la lengua hebrea. ${ }^{110}$ Esta disputa supuso la caída en desgracia de Měnahemem b. Saruq, que perdió el favor de su mecenas, su casa fue demolida y él, golpeado en público y encarcelado hasta el punto de que no sabemos nada más sobre su paradero o suerte.

En cambio los discípulos de Měnaḥem b. Saruq sí suponen un avance en materia filológica y, por primera vez, se llevará a cabo la adaptación gramatical, de manera implícita, del paradigma fa 'ala para la lengua hebrea. En un primer momento, muy experimental, se trata de ordenar esquemas nominales para lanzar ataques contra la métrica adaptada por Dunaš ben Labraț, al que demostrarán que la métrica árabe, desde su preceptiva más clásica, no puede aplicarse en el caso del hebreo por la acumulación constante de letras quiescentes en las palabras. ${ }^{11}$

Los autores de esta primera generación pusieron de manifiesto que la lengua hebrea sí podía adaptarse no solo a la métrica árabe, sino que, además, aceptaba las teorías lingüísticas desarrolladas por los musulmanes para estudiar su lengua. De ahí el esplendor alcanzado por la lengua hebrea en al-Andalus, pues vino a formar parte integrante de la cultura andalusí en sus más importantes niveles. Hoy en día, es de recibo general que la primera generación de intelectuales judíos autóctonos rechazó la comparación o similitud del hebreo con el árabe. Sin embargo, en realidad, sólo se negaron a una comparación explícita y exagerada. Los autóctonos no aceptaban que las tres lenguas, hebrea, aramea y árabe, fuesen idénticas. Su declaración de principios es muy clara: ${ }^{112}$ ¿qué tienen en común el hebreo y el arameo? Si en cada una de las palabras a las que no hallas paralelos, dijésemos que tiene similares en las lenguas aramea y árabe, resultarían lenguas idénticas, y conoceríamos ese resto de la lengua hebrea que ha desaparecido y nos falta.

Este mismo formato de réplica es el que encontramos en la obra de Adonia ha-Levī, tanto tiempo confundido con Dunaš ben Labraț. ${ }^{113}$ Re'arūẹ"'.

110 Corriente, "Métrica hebrea cuantitativa, métrica de la poesía estrófica andalusí y

111 Sáenz-Badillos, "Los discípulos de Měnahem sobre la métrica hebrea".

112 Benavente, Tešubot de los Discípulos de Měnaḥem, pp. 54*-55* y 88.

113 Véase la nota 20. 
dactada en época 'Āmirī, su autor se atrevió a dar un paso más allá y cuestionar al propio Să'adyah al-Fayyūmī de Babilonia, dando testimonio de que, como comunidad, eran conscientes de haber superado, al menos en materia filológica, a los sabios de Oriente.

Este mismo prestigio como especialista o šayh estaba en juego en la polémica protagonizada por Ibn Nagrela e Ibn Ğanāh justo después de abandonar Córdoba. El primero acababa de cumplir veinte años y quizá fuese ese el motivo por el que se mantiene en el anonimato a lo largo de toda esta disputa bajo el seudónimo rifāq 'compañeros'. ${ }^{114} \mathrm{El}$ objetivo de su crítica era descalificar, incluso mofarse, de un Ibn Ğanāḥ que habiendo alcanzado ya la madurez y completado todas las etapas de su formación se consagró como una de las máximas autoridades en lengua hebrea, primero en al-Andalus y tras su muerte a nivel internacional gracias a las traducciones de su obra por Yěhudah ibn Tibbon entre otros. ${ }^{115}$ La defensa de su prestigio le lleva a insultar descaradamente a sus oponentes, siendo especialmente duro en su Risālat altanbīh 'Epístola de la advertencia'. ${ }^{116}$

Ibn Ğanāh nos ha dejado un precioso testimonio de estas tertulias en su obra Kitāb al-tašwi'ah. ${ }^{117}$ La tertulia se celebró en Zaragoza, en casa de Sulaymān ibn Țarāqa. Resulta muy curioso que determinados epígrafes $(2 \S, 12 \S)$ conserven la estructura típica de este tipo de textos tal y como la encontramos en los autores de la primera generación, es decir, exposición de hechos lingüísticos, discusión y descalificación pública mediante fórmulas que pretenden mofarse del adversario: ¡Ojalá supiese yo qué presa es esta a la que da caza el polvo! ¿Una gacela o una cabra? (p. 134), abandonar el camino abierto y meterse por los senderos en los que se esconden los cocodrilos no es una buena solución (p. 150), o incluso en verso al final, si vuelve el alacrán volveremos a él / y el zapato va a estar preparado para él (p. 152), a manera de "continuará si continúan", entre otras. A pesar de que Ibn Ğanāḥ reconoce que no ha pretendido acusar de ignorancia (a nadie) pues no es (propio) de mi carácter ni de mi condición y preferí callarme (p. 151), lo cierto es que no parece disgustarle del todo que la disputa gire

114 Para la edición de los breves fragmentos véase la nota 24.

115 Ya he recogido las ediciones de estas traducciones en la nota 23.

116 Martínez Delgado, 'Risālat al-Tanbīh', pp. 311-313.

117 Gallego, El judeo-árabe medieval. Todas las referencias de este párrafo aluden a esta edición. 
en torno a sus palabras, de hecho llega a reconocer que lo único que yo me propuse con este libro es daros a conocer la explicación de aquellas partes del Mustalhaq que han sido contradichas, a pesar de que están claras para quien haya reflexionado sobre ellas (p. 141). ¿Qué es lo que se está discutiendo en realidad en esta disputa? Convencido de que está rodeado de ignorantes que se dedicaron a una disciplina para la que no sirven y se adentraron en una cuestión para la que no están capacitados (p. 131), que son el fruto de la ignorancia y el producto de la envidia (p. 131) y que según él desconocen el funcionamiento de las letras débiles hebreas (p. 141: no es mi obligación aclararlo), no duda en humillar a su interlocutor con fórmulas tipo ¿Vosotros habéis entendido lo que dijo Abū Zakariyyā' al final de ese capitulo? (p. 137). La verdad es que su adversario, tal y como lo describe Ibn Ğanāh, más que un lingüista es un aficionado que algo ha oído sobre gramática, terco e incapaz de dominar la conjugación verbal de forma improvisada, situación que provoca la mofa descarada del autor que dice sufrir un desvanecimiento similar al de los epilépticos (p. 138) ante los desvaríos lingüísticos del aprendiz de su auténtico adversario, que siempre permanece en el anonimato (al-qawm).

Concluida esta etapa de formación, el alumno ya no era tal, sino un especialista y podía aventurarse a redactar obras que en realidad eran revisiones de los grandes clásicos de referencia durante la etapa secundaria. Encontramos al menos dos obras de la época que comparten estas características y diseñadas como complementos anexos al libro de Ḥayyūğ: Kitāb al-Mustalhaq de Ibn Ğanāh ${ }^{118}$ y un libro de verbos hebreos anónimo dedicado a los binyanim en los que funcionan las raíces verbales recopiladas por Ḥayyūğ. ${ }^{119}$

Este período toca su fin desde un punto de vista intelectual con la aparición de algunas de las obras que forman parte del siglo de Oro de las letras hebreas en al-Andalus (segunda mitad siglo XI - primera mitad siglo XII) como los dos grandes diccionarios de la lengua hebrea, las monografías especializadas y los comentarios exegéticos de corte filológico. ${ }^{120}$ Aunque los datos incluidos en este trabajo no resulten no-

118 Derenbourg y Derenbourg, Opuscules et traités d'Abou'l-Walid, pp. 1-246.

119 Martínez Delgado, "An Anonymous Book on Hebrew Verbs in Judeo-Arabic".

${ }^{120}$ Para esta nueva etapa véase por ejemplo Sáenz-Badillos y Targarona, Gramáticos hebreos de al-Andalus, pp. 93-156; Sáenz-Badillos, Literatura hebrea en la España medieval, pp. 79-124. 
vedosos, su descripción sí lo es y ha estado apoyada constantemente en fuentes históricas y literarias que justifican una nueva exposición de hechos y datos conocidos que creo han quedado integrados ahora en su contexto arabo-islámico. Esta actividad intelectual judeo-andalusí durante el califato omeya de Córdoba encaja perfectamente en la descripción de hechos que M. 'Abd al-Hamid 'Isa desarrolla en su obra Ta'rīh al-ta 'lim fi l-Andalus para el mismo periodo en el caso de los musulmanes, confirmando que, desde un punto de vista político, el esplendor alcanzado por los judíos durante el período de taifas es resultado de un proceso que fue madurando gracias a las políticas educativas y de mecenazgo aplicadas por los califas omeyas en Córdoba y de las que los judíos participaron y se beneficiaron explotándolas hasta sus últimas consecuencias.

\section{Bibliografía}

Abramson, Shrega, “'Al pĕraṭ eḥad bě-ḥayye R. Y. ben Ǧanāḥ”, Tarbiz, 12, 4 (1941), pp. 300-301.

Alahmad Alkhalaf, Ahmad y Martínez Delgado, José, Risālat al-taqrīb wa-l-tashīl de Abū l-Walìd Marwān ibn Ğanāh de Córdoba. Edición diplomática y traducción, Madrid, 2018.

Al-Idrīsī, Description de l'Afrique et de l'Espagne, Reinhart Dozy y Michael Jan de Goeje (ed. y trad.), Leiden, 1866

Al-Hušanī, Historia de los jueces de Córdoba, Julián Ribera (texto árabe y traducción española), Madrid, 1914.

Allony, Nehemyah, The Scansion of Medieval Hebrew Poetry (en hebreo), Jerusalén, 1951.

Allony, Nehemyah, Ha'egron Kitāb 'ușūl al-shi 'ir al- 'ibrān̄̄ by Rav Sĕ 'adya Ga'on, Critical Edition with Introduction and Commentary,Jerusalén, 1969.

Al-Maqqarī, Nafh al-ṭ̂̄b, Iḥsān 'Abbās (edición), Beirut, 1968.

Al-Muqaddasī, Kitāb aḥsan al-taqāsīm fì ma 'arifat al-aqalim, Michael Jan de Goeje (edición), Leiden, $1906^{2}$.

Ashtor, Eliyahu, The Jews of Moslem Spain, Filadelfia, 1973.

Asín Palacios, Miguel, Abenházam de Córdoba y su Historia crítica de las ideas religiosas, Madrid, 1984.

Arjona Castro, Antonio, "La judería en la Córdoba del emirato y califato", Anaquel de Estudios Árabes, 11 (2000), pp. 101-107.

Bacher, William, Sepher haschoraschim, Wurzelwörterbuch der hebräischen Sparche von Abulwalîd Merwân Ibn Ğanâh (R. Jona) Aus dem Arabischen in's Hebräische übersetzt von Jehuda Ibn Tibbon, Berlín, 1896. 
Basal, Nasir, Kitāb al-nutaf lě-rabī Yěhudah Hayyūğ, Tel Aviv, 2001.

Becker, Dan, The Risāla of Judah ben Quraysh, a Critical Edition, Tel Aviv, 1984. Becker, Dan, Arabic Sources of R. Jonah ibn Janāh's Grammar, Tel Aviv, 1998. Benavente, Santiaga, Tešubot de los Discípulos de Měnahem contra Dunaš ben Labrat. Edición del texto y traducción castellana, Granada, 1986.

Ben-Ḥayyim, Zeev, “Lě-“inyan kělale ha-šěwa’ šel R. Yěhudah Ḥayyūğ”, Leshoпепи, 20 (1956), pp. 135-138.

Bos, Gerrit, y Kas, Fabian, “Arabic Pharmacognostic Literature and Its Jewish Antecedents: Marwān ibn Ğanāḥ (Rabbi Jonah), Kitāb al-Talhūiṣ”, Aleph, 16, 1 (2016) pp. 145-229.

Busi, Giulio, 'Materiali per una storia della filologia e dell'esegesi ebraica: Abū 'l-Walīd Marwān ibn Ğanāḥ', Annali, 46, 2 (1986), pp. 167-195.

Camacho Padilla, José Manuel, 'Rabí Yonâ ben Gannach. La segunda mitad del Sefer Hahaxua, versión hebraica de su Kitab at-Tasuiya, por Salomón bar Yosef ben Ayyub', Boletín de la Real Academia de Ciencias, Bellas Letras y Nobles Artes de Córdoba, 25 (1929), pp. 23-72.

Cano, María José, Yiṣhaq ibn Jalfun. Poeta cortesano cordobés, Córdoba, 1988.

Carmona Berenguer, Silvia, "Casa pórtico de época califal en el arrabal noroccidental de Córdoba", Anales de Arqueología Cordobesa, 8 (1997), pp. 213 228.

Corriente, Federico, "Métrica hebrea cuantitativa, métrica de la poesía estrófica andalusí y 'arụḍ", Sefarad, 46 (1986), pp. 123-132.

Derenbourg, Joseph, Livre des parterres fleuris; grammaire hébraïque en arabe d'Abou 'l-Walid Merwan ibn Djanah de Cordoue, París, 1886.

Derenbourg, Joseph y Derenbourg, Hartwig, Opuscules et traités d'Abou'l-Walid Merwan ibn Djanah de Cordoue: texte arabe, publié avec une traduction française, París, 1880.

Dietrich, Albert, "Ibn Djuldjul”, The Encyclopaedia of Islam New Edition (1979), Vol. III, pp. 755-756.

Dozy, Reinhart, Histoire des Musulmans d'Espagne: jusqu'à la conquête de l'Andalousie par les Almoravides (711-1110). Tome troisième: Le Califat, Leiden, 1861.

Eldar, Ilan, "Gilgulo šel musag al-sākin al-layīn (ha-naḥ ha-rafeh) mi-Sěfarad lě'ereș Yiśra'el”, Miscelánea de Estudios Árabes y Hebraicos, 33, 2 (1984), pp. 1-9.

Eldar, Ilan, "The Grammatical Theory of Hayyūj” (hebreo), Leshonenu, 54 (1990), pp. 169-181.

Elizur, Shulamit, "Ḥiddušim bĕ-ḥeqer ha-širah wě-ha-piyyuṭ", en D. Rosenthal, The Cairo Geniza Collection in Geneva. Catalogue and Studies, Jerusalén, 2010, pp. 200-207.

Elwolde, John, “The Mahberet of Menahem-Proposals for a Lexicographic Theory, with Sample Translation and Notes", en J. Davies, G. Harvey and W. G. 
E. Watson (eds.), Words Remembered, Texts Renewed. Essays in Honour of John F.A. Sawyer, Sheffield, 1995, pp. 462-479.

Fenton, Paul, "Jonah Ibn Ganāḥ's Medical Dictionary, the Kitāb al-Talhụ̄ṣ: Lost and Found", Aleph, 16, 1 (2016), pp. 107-143.

Filipowski, Herschell, The first Hebrew and Chaldaic Lexicon to the Old Testament / compiled in the tenth century by Menahem ben Saruk, the Spaniard; selected and translated from the original Hebrew; accompanied by a biography of the author as collected from a recent Hebrew work of S. D. Luzzatto, Londres, 1854.

Filipowski, Herschell, Těšubot Dunaš ben Labraț 'im hakra' ot Rabenu Ya 'aqob Tam, heleq šeni le-sefer Mahberet Menahem, Londres-Edinburgo, 1855.

Fleischer, Ezra, "Lě-qadmuniyot širatenu bi-Sfarad. 'Iyyun ba-širim šel rabbi Měnahem ben Saruq", Asufot, 2 (1988), pp. 227-269.

Gaash, Amir, “The Responses (Teshuvot) of Menahem's Disciples against Dunash: Who Authored Which Response, and Was Hayyūj One of the Disciples?" (en hebreo), Leshonenu, 81 (2019), pp. 297-318.

Gallego, María Ángeles, El judeo-árabe medieval: edición, traducción y estudio lingüístico del Kitāb al-taswi'a de Yonah ibn Ğanāh, Berna, 2006.

Garijo-Galán, Ildefonso, “[1396] Ibn Ŷulŷul, Sulaymān”, Enciclopedia de la Cultura Andalusi / Biblioteca de al-Andalus, vol. 6, pp. 163-166.

Gil, Moshe, In the Kingdom of Ishmael (en hebreo), Jerusalem, 1997.

González, Julio, Reinado y diplomas de Fernando III, Córdoba, 1986.

Hazon, Raaya, "Sefer Tiqqun Shegagot: Its Author and Other Issues" (en hebreo), en M. Bar-Asher y C. E. Cohen (eds.), Mas 'at Aharon: Linguistic Studies Presented to Aron Dotan, Jerusalén, 2009 pp. 289-304

Hiedra Rodríguez, Enrique, "Ibn Shuhayd on Joseph; A Muslim Poet at the Gate of the Jews", en Charles Burnett \& Pedro Mantas (eds.), Mapping Knowledge. Cross-Pollination in Late Antiquity and Middle Ages, Córdoba, 2014, pp. 167179.

Ibn Daud, Sefer ha-Qabbalah, The Book of Tradition, Gerson D. Cohen (ed. y transl.), Filadelfia, 1967.

Ibn 'Ezra, Kitāb al-muḥādara wal-mud̄ākara, Montserrat Abumalham Mas (ed. y trad.), Madrid, 1986.

Ibn Ğanāh, The book of Hebrew roots, new first ed. by Adolf Neubauer with an appendix, containing extracts from other Hebrew-Arabic dictionaries, Oxford, 1873-1875.

Ibn Ǧinn̄̄, al-Hașā'is, Muhammad 'Alī-l-Naŷŷār (ed.), Beirut, 1956.

Ibn Hayyān, El califato de Córdoba en el "Muqtabis" de Ibn Hayyān, Anales palatinos del califa de Córdoba al-Hakam II, por 'İsā ibn Ahmad al-Rāzī (306364 H. = 971-975 J.C.), Emilio García Gómez (trad.), Madrid, 1967.

Ibn 'Id̄ārī al-Marrāqušī, Kitāb al-bayān al-mugrib fì ahbār mulūk al-andalus wal-magrib al-gǔz'u al-tañi, ta'rih̆ al-Andalus min-al-fatḥ ilā al-qarn al-rabi ‘ 
al-higřr tome II, Histoire de l'Espagne musulmane de la conquête au XIe siecle: et fragments de la chronique de Arib, Georges S. Colim y Evariste Lévi (ed.), Leiden, 1951.

'Īsā, Muḥammad 'Abd al-Ḥamīd, Tārīh al-ta 'ìm fì l-Andalus, Cairo, 1982.

Jastrow, Morris, The weak and geminative verbs in Hebrew by Abû Zakariyyâ Yahyâ ibn Dâwud of Fez, known as Hayyûg; the Arabic text now published for the first time, Leiden, 1897.

Kokóvtsov, Pavel K., Novye materīaly dlia kharakteristiki İekhudy Khaŭiudzha, Samuila Nagida i niekotorykh drugikh predstavitelě evrě̌skoŭ filologicheskor nauki v X, XI i XII viekie, San Petersburgo, 1916.

Lameer, Joep, Al-Fārābī and Aristotelian Syllogistics: Greek Theory and Islamic practice, Leiden-New York, 1994.

Larrea Castillo, Isabel y Hiedra Rodríguez, Enrique, "La lápida hebrea de época emiral del Zumbacón. Apuntes sobre arqueología funeraria judía en Córdoba", Anejos de Anales de Arqueología Cordobesa, 2 (2009), pp. 327-342.

Lévi-Provençal, Evariste, al-Bayān al mugrib fì ahbār mulūk al-Andalus wa-alMaghrib. Tome troisième, Histoire de l'Espagne musulmane au XIème siècle. Texte arabe publié pour la première fois d'après un manuscrit de Fès, Texte et indices, Paris, 1930.

Má́llo Salgado, Felipe, La caída del Califato de Córdoba y los reyes de taifas: (al-Bayān al-Mugrib) Ibn 'Idāāī; estudio, traducción y notas, Salamanca, 1993.

Maman, Aharon y Ben-Porat, Efraim, Kitāb al-nutaf R. Yehudah Hayyūj's Philological Commentary to the Books of Prophets in 'Ali ibn Suleymān Compendium, Introduction, Annotated Edition and Translation, Jerusalem, 2012.

Martínez Delgado, José, Yahyà Ibn Dāwūd: El Libro de Hayyūŷy (Versión original árabe siglo X). Introducción y Traducción, Granada, 2004.

Martínez Delgado, José, "El Opúsculo sobre la Normativa Vocálica (Kitāb šurūṭ al-naqt) de Hayyūŷ (edición y traducción)", Miscelánea de Estudios Árabes y Hebraicos, Sección Hebreo, 54 (2005), pp. 185-230.

Martínez Delgado, José, “[1354] Ibn Ŷanāḥ, Marwān”, Enciclopedia de la Cultura Andalusí / Biblioteca de al-Andalus, Vol. 6, Almería, 2009, pp. 88-95.

Martínez Delgado, José, "From Bible to lexicography through the masora on alAndalus: the use of the Sefer 'okla we-'okla among the first Andalusi Hebrew philologists", en J. P. Monferrer-Sala y Á. Urbán (eds.), Sacred Text, Explorations in Lexicography, Frankfurt am Main, 2009, pp. 167-197.

Martínez Delgado, José, "Ibn Janāḥ, Jonah (Abū 'l-Walīd Marwān)”, Encyclopedia of Jews in the Islamic World, Vol. II, pp. 500-503, Leiden, 2010.

Martínez Delgado, José, "The Arabicization of the Hebrew morphology in al-Andalus: the adaptation of the fa'ala paradigm", en J. P. Monferrer \& N. al Jallad, The Arabic language across the ages, Wiesbaden, 2010, pp. 49 - 63. 
Martínez Delgado, José, "El uso del Mahberet entre los principales filólogos hebreos de Alandalús (siglos X-XI)", Miscelánea de Estudios Árabes y Hebraicos, sección Hebreo, 59 (2010), pp. 135-165.

Martínez Delgado, José, "La carta al rey de los Jazares", en M. J. Cano Pérez y T. M. García Arévalo, Oriente desde Occidente. Los escritos de viajes judíos, cristianos y musulmanes sobre Siria-Palestina (ss. XII-XVII), Granada 2012, vol. I, pp. 155-187.

Martínez Delgado, José, “An Anonymous Book on Hebrew Verbs in Judeo-Arabic", Revue des Études Juives, 173, 3, 4 (2014), pp. 325-359.

Martínez Delgado, José, "Risālat al-Tanbīh by Ibn Ğanāḥ: an Edition, Translation and Study", Jerusalem studies in Arabic and Islam, 43 (2016), pp. 309-355.

Martínez Delgado, José, Un manual judeo-árabe de métrica hebrea andalusí (Kitāb 'arụ̣̄ al-ši 'r al- 'ibrī) de la Genizah de el Cairo. Fragmentos de las colecciones Firkovich y Taylor-Schechter. Edición diplomática, traducción y estudio, Córdoba, 2017.

Metzger, Mose, Le livre des parterres fleuris d'Abou'l-Walid Merwan ibn Djanah, traduit en français sur les manuscrits arabes, Paris, 1889.

Mohamed, Ramadan I. M., "La epistemología de al-Qirqisānī y su vinculación con el kalām islámico", Astarté. Estudios del Oriente Próximo y el Mediterráneo, 1 (2018), pp. 103-126.

Morag, Shlomo, "Maḥăloqet Měnaḥem wě-Dunaš wě-tahălik ha-těhịyyah ha'ibrit bi-Sfarad”, Pe 'amim, 56 (1993), pp. 4-19.

Munk, Salomon, "Notice sur Abou'l-Walid Merwan Ibn Djana'h et sur quelques autres grammairiens hébreux du Xe et du XIe siécle”, Journal Asiatique IV t. XV (1850), pp. 297-337; t. XVI pp. 5-50 (1851), pp. 201247, pp. 353-427.

Ŏkláh wě-Oḱláh, Fernando Díaz Esteban (ed.), Madrid, 1975.

Pèrés, Henri, La poésie andalouse en arabe classique au XIe siècle; ses aspects generaux, ses principaux themes et sa valeur documentaire, Paris 1953.

Pétrof, Dmitri K., Abû-Muhammed-Alî-ibn-Hazm al-Andalusi, Tauk-al-hamâma, Leiden 1914.

Rosado Llamas, María Dolores, La dinastía hammudi y el califato en el siglo XI, Málaga, 2008.

Sáenz Badillos, Ángel, Tešubot de Dunaš ben Labrat. Edición crítica y traducción española, Granada, 1980.

Sáenz Badillos, Ángel, "Les Tešubot de Dunaš ben Labraṭ contre le Maḥberet de Měnahem. Matériaux Nouveaux”, en P. Casetti, O. Keel, A. Schenker (eds.), Mélanges Dominique Barthélemy, Fribourg, Suisse - Göttingen, 1981, pp. 347-371.

Sáenz Badillos, Ángel, "La hermenéutica bíblica de Dunaš ben Labraț”, en N. Fernández Marcos, J. C. Trebolle Barrera, J. Fernández Vallina (eds.), Simposio Bíblico Español (Salamanca 1982), Madrid, 1984, pp. 697-706. 
Sáenz Badillos, Ángel, "Los hapax legomena bíblicos en Měnaḥem ben Saruq”, en D. Muñoz León (ed.), Salvación en la Palabra. Homenaje al Prof. A. Díez Macho, Madrid, 1986, pp. 783-809.

Sáenz Badillos, Ángel, Maḥberet Měnaḥem ben Saruq, Granada, 1986.

Sáenz Badillos, Ángel, Historia de la lengua hebrea, Sabadell, 1986.

Sáenz Badillos, Ángel, "Los discípulos de Měnaḥem sobre la métrica hebrea", Sefarad, 46 (1986), 421-431.

Sáenz Badillos, Ángel, Literatura hebrea en la España medieval, Madrid, 1991. Sáenz Badillos, Ángel, "Sobre el autor de las Tešubot 'al Sĕ'adyah [British Library, Add. 27214]", en A. Mirsky, A. Grossman, Y. Kaplan (eds.), Exile and Diaspora: Studies in the History of the Jewish People Presented to Professor Haim Beinart, Jerusalem, 1991, pp. 26-43.

Sáenz Badillos, Ángel y Martínez Delgado, José, "En torno al Maḥberet de Měnahem ben Saruq”, en José Martínez Delgado (ed.), Ángel Sáenz-Badillos Pérez, Lengua y literatura de los judios de al-Andalus (Siglos X-XII), Granada 2015, pp. 85-141.

Sáenz-Badillos, Ángel y Targarona, Judit, Gramáticos hebreos de al-Andalus (siglos X-XII) Filología y Biblia, Córdoba, 1988.

Sáenz-Badillos, Ángel y Targarona, Judit, Los judios de Sefarad ante la Biblia: la interpretación de la Biblia en el medievo, Córdoba, 1993.

Sara, Solomon I. y Mauck, Simon M., Yehuda ben David Hayyuwj: Tanqiyt: a treatise on Hebrew vowels, translation, notes and analysis, München, 2005.

Schirmann, Jeffim, Ha-širah ha- 'ibrit bi-Sfarad u-b̌e-Provans, Jerusalem, 19541959.

Schirmann, Jeffim, The History of Hebrew Poetry in Muslim Spain, edited, supplemented and annotated by Ezra Fleischer (en hebreo), Jerusalem, 1995.

Schröter, Robert, Kritik des Dunasch ben Labrat, Breslau, 1866.

Sivan, Daniel, "Hayyūğ hayah hogeh qameș sěfardi”, Leshonenu, 53 (1988-89), pp. 90-92.

Sivan, Daniel, "Biblical Hebrew Roots and Quiescents According to Judah Hayyuj's Grammatical Works", Hebrew Union College of America, 60 (1989), pp. 115-127.

Sivan, Daniel y Wated, Ali, Three treatises on Hebrew grammar by Judah Hayyuj: a new critical edition of the Arabic text with a Modern Hebrew translation, Beersheba, 2012.

Stern, Solomon Gottlieb, Těšubot talmide Menahem ben Saruk 'al těšsubot Dunaš ben Labrat wě- těšubot talmid Dunaš ben Labraț, Vienna, 1870.

Stroumsa, Sarah, "Between Acculturation and Conversion in Islamic Spain the Case of the Banū Hasday", Mediterranea. International journal for the transfer of knowledge, 1 (2016), pp. 9-36

Targarona Borrás, Judit, "Breves notas sobre Yosef ibn Abitur", Miscelánea de Estudios Árabes y Hebraicos, 31, 2 (1986), pp. 53-85. 
Téné, David, Sefer ha-Hassaga which is Kitab al-Mustalhaq of rabbi Jonah Ibn Janah in the Hebrew translation of 'Obadiah ha-sĕfaradi: a critical edition based on two manuscripts and compared to the Arabic original with an introduction, notes, and an index of Biblical sources; posthumous work edited by Aharon Maman, Jerusalem, 2006.

Téné, David, "Ibn Janāḥ, Jonah", Encyclopaedia Judaica Second Edition, Vol. 9 (2007), pp. 680-683.

Varela Moreno, María Encarnación, Tešubot de Yehudi ben Šešet. Edición, traducción y comentario, Granada, 1981.

Versteegh, Kees H. M., "The Origin of the Term qiyās in Arabic Grammar", Zeitschrift für arabische Linguistik, 4 (1980), pp. 7-30.

Vidro, Nadia, Verbal Morphology in the Karaite Treatise on Hebrew Grammar Kitāb al- 'uqūd fì tașārīf al-lugia al- 'ibrāniyya, Leiden-Boston, 2011.

Wilensky, Michael, Sefer ha-riqmah (Kitāb al-luma') lě-R. Yona ibn Ğanāh bĕtirgumo ha- 'ibri šel Yěhuda ibn Tibbon, Berlin 1929

Yahalom, Joseph, Judaeo-Arabic Poetics, Fragments of a Lost Treatise by El 'azar ben Jaqob of Baghdad (en hebreo), Jerusalem, 2001.

Yahalom, Joseph y Sáenz-Badillos, Ángel, “"Ariknah wěnusaḥ bě-kitbe ha-yad šel Mahberet Měnahem", Leshonenu, 48-49 (1985-86), pp. 253-268.

Zanón, Jesús, Topografía de Córdoba Almohade a través de las fuentes árabes, Madrid, 1989.

Zulay, Menahem, “Azharot R. Yiṣhaq b. Ğiqațela”, Tarbiz 20.1 (1949-50), pp. 161-176.

Recibido: $13 / 07 / 2018$

Aceptado: 23/09/2019 